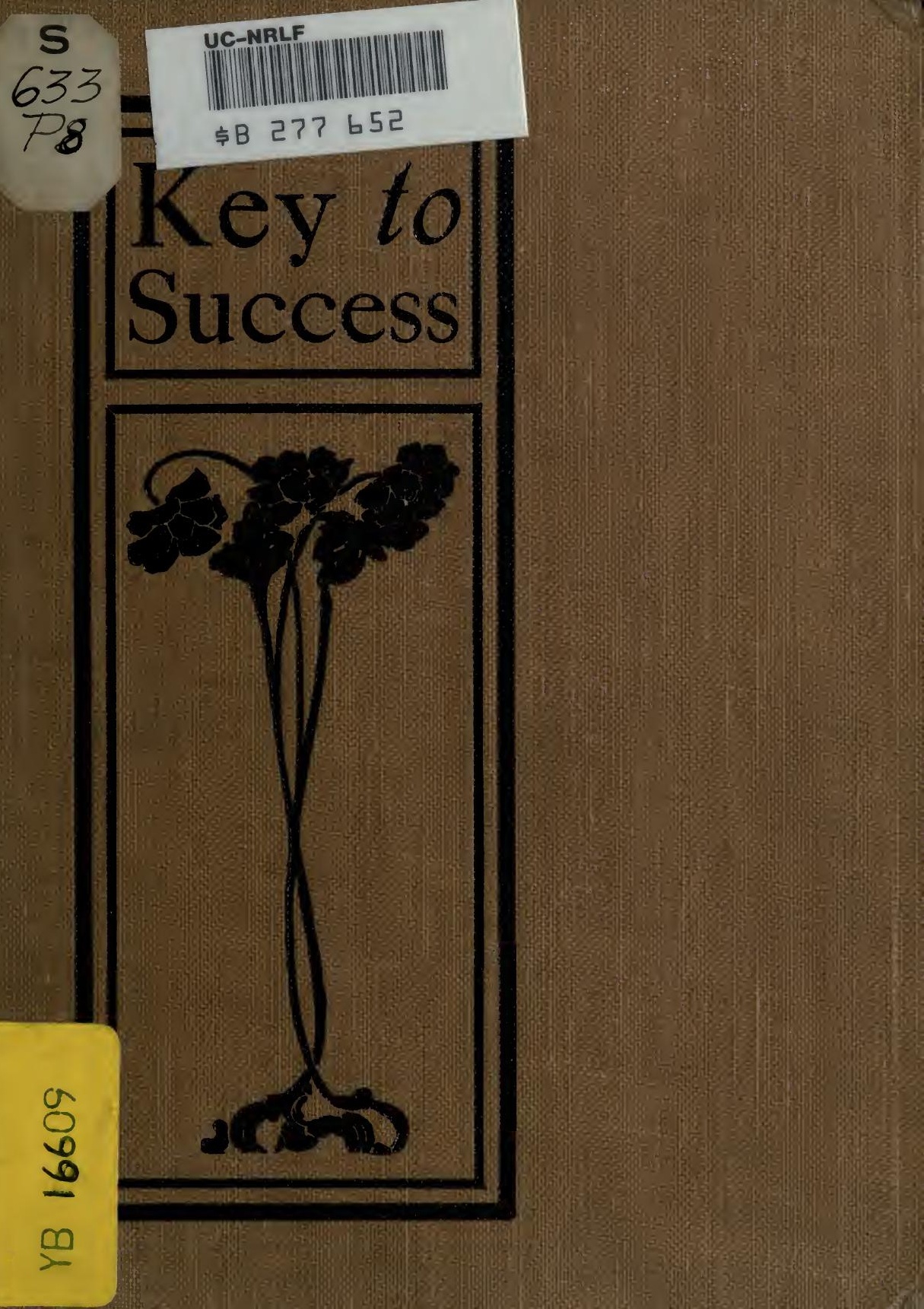




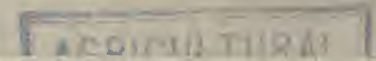
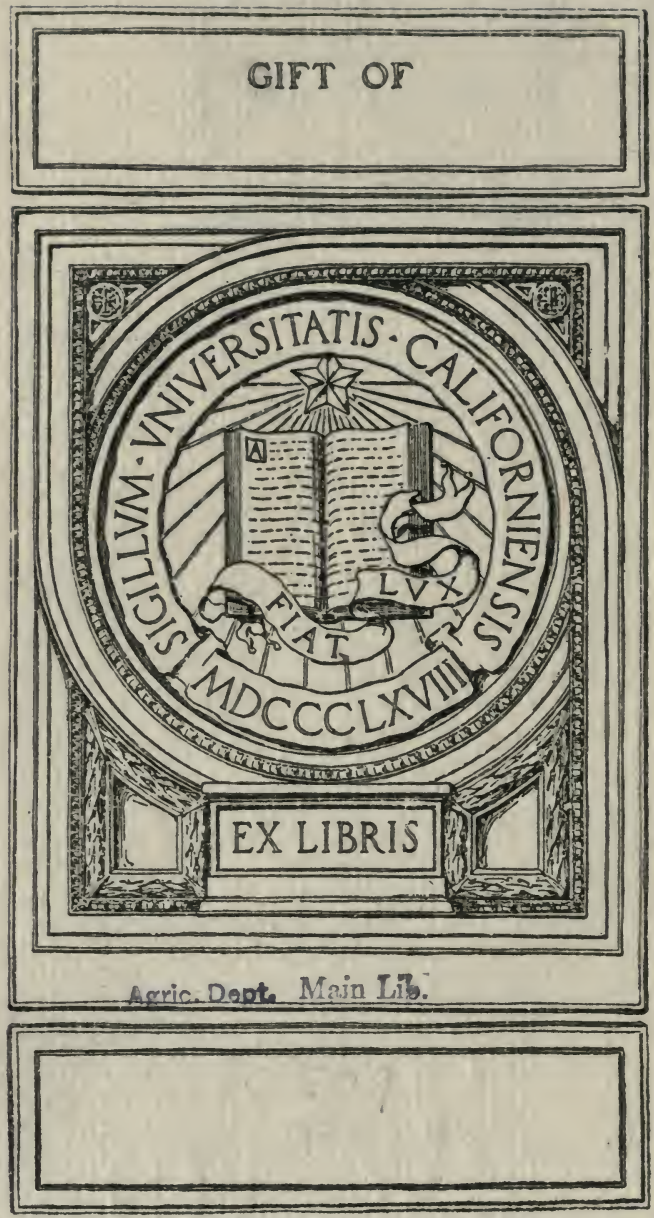
Compliments ghe Author Ners. Mid. S. Prange. 
Digitized by the Internet Archive in 2007 with funding from Microsoft Corporation

http://www.archive.org/details/keytosuccessgene00pranrich 
Wilson $\Xi$ Toomer

Fertilizer Co.

\title{
Key to Success
}

\author{
v \\ "Wouldst have abundant crops reward thy toil \\ And fill thy barns, $O$ tiller of the soil ? \\ Then ever keep in mind this maxim true, \\ Feed well the land, and 'twill in turn feed you." \\ Q
}

Price, Twenty-five Cents, Postpaid.

Cloth Bound, Fifty Cents. 


\section{Free Booklets}

How and When to Fertilize Citrus Trees

Full Crops-Half Drops

Good Fruit

For Value Received

(The last three issued in season)

Lime: Its Forms and Effects

Florida Vegetables

Irish Potatoes

Melons and Cucumbers

Florida Strawberries

Pecans

Cotton Farming

More Cotton-Less Work

Lower East Coast Section

Ideal Fertilizers, a booklet giving the analyses, prices, etc., of our different brands.

Citrus Culture for Profit.-This work covers citrus culture from selection of land to marketing, including latest methods of insect and disease control. Cloth bound, 50 cents; paper covers, 25 cents.

Control of Insects and Diseases in Grove, Garden and Field.-A complete treatise describing the different insects and diseases and means of prevention, control and remedy, including crop rotation, recipes for making and mixing insecticides and fungicides, directions for their use and description of effective spraying implements. Price 50 cents. 


\section{Key to Success}

General Principles

of

Soil Management

by

N. M. G. Prange

Wilson \& Toomer Fertilizer Co. Publishers 


$$
\frac{5633}{78}
$$

\section{To Our Friends}

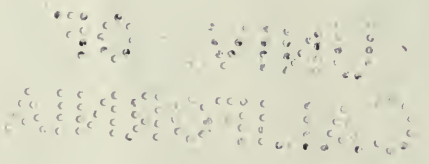

Copyright, 1913, by

Wilson \& Toomer Fertilizer Co.

All rights reserved 


\section{Preface}

Again we make our bow to the public who has ever received us so kindly. "Key to Success" is a fitting name for this little book, as it is an easily read statement of the general principles of soil management and conservation.

The information is based on a personal experience in Florida during the past twenty-five years supplemented by the field experience of many others, and a study of all the leading authorities in this line of work.

Thanking our many friends for their hearty co-operation in our educational work,

Very respectfully,

- Wilson \& Toomer Fertilizer Co.

March, 1913. 


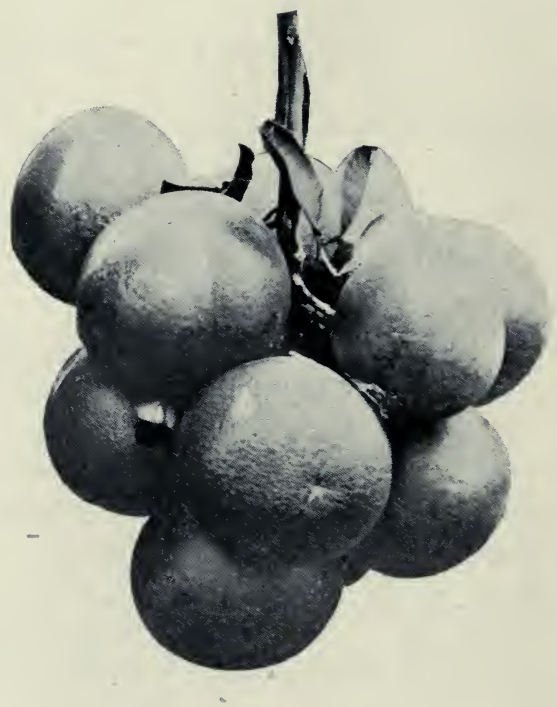




\section{CONTENTS}

Chapter I

Soil

Chapter II

Soil Preparation

Chapter III

Management of Different Soils

Chapter IV

Lime

Chapter V

Starting the Grove

Chapter VI

What a Fertilizer Tag Means

Chapter VII

Home Mixing

Chapter VIII

Effect of the Different Elements

Chapter IX

Fertilizer Materials

Chapter X

Plant Constituents

Chapter XI

Fertility

Chapter XII

Insects in General

Chapter XIII

Diseases in General

Chapter XIV

Spraying 


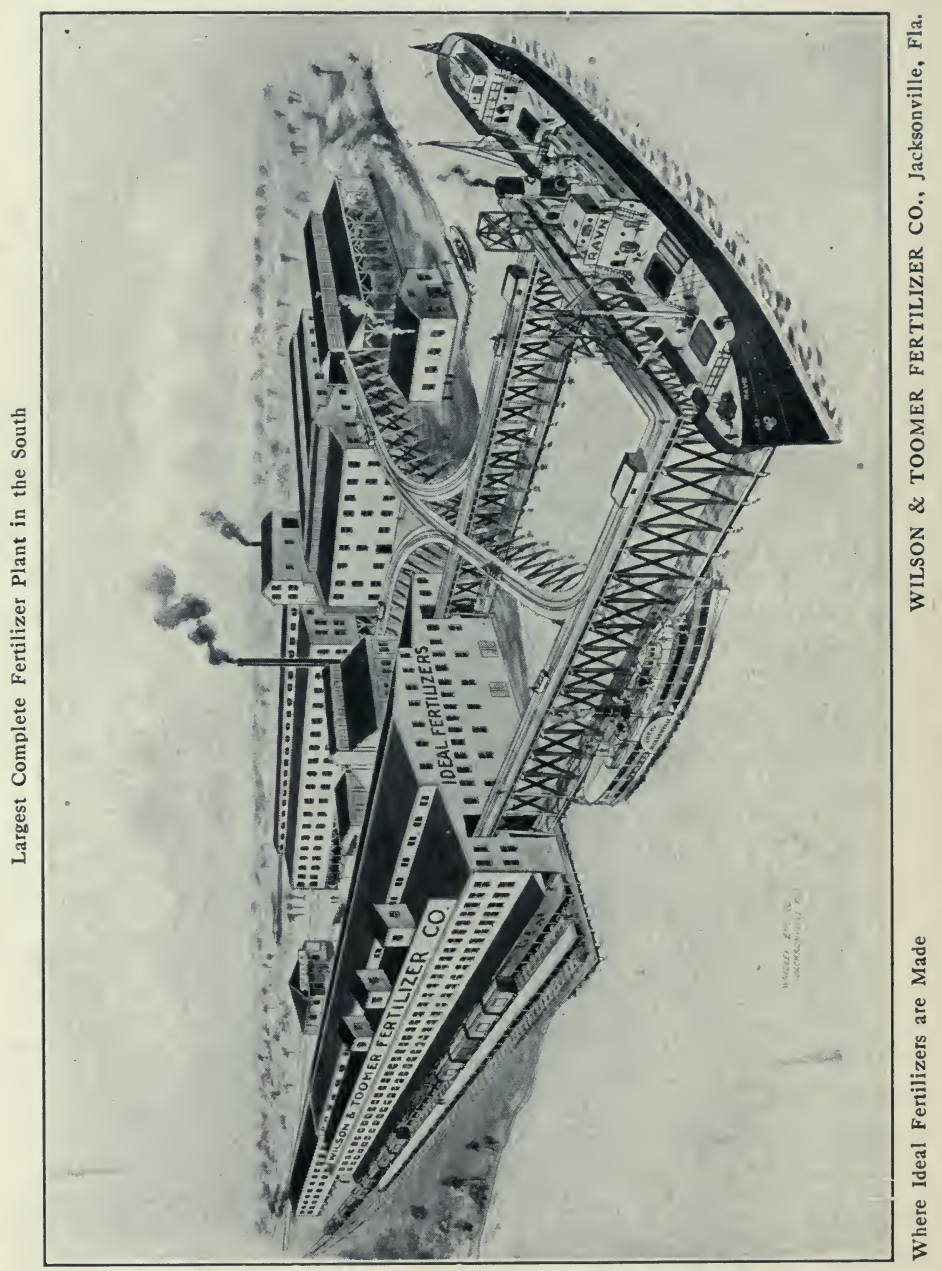




\section{Chapter I.}

\section{Soil}

About the first point taken up by the grower who is starting in to "do things right" is soil analysis. It seems such a simple solution of all questions on fertilization and such an insurance of success. "Analyze the soil; compare that with the general analysis of the crop to be grown; buy the lacking ingredients. Why doesn't everyone who cares at all for success go to this slight trouble and expense?" Alas! the disappointment and (often) incredulity when told the plan is not feasible; that the real starting point is the texture of the soil; that the right content of air, water, and humus for the greatest activity of our friendly bacteria must be secured before the best of fertilizers can bring about maximum productiveness.

Productiveness-That is what we Floridians like to talk about. Newcomers may laugh at our "sand" but when they hear how much that sand produces they look at it with respect. With our soil and climate, opportunities are unlimited. If Florida is a "lazy man's country" it is simply because the lazy man can exist here more easily than in a colder clime, not at all because there is not a chance for his energetic brother to reap full reward for his activities. 


\section{Varieties}

We have many varieties of soil,- the almost pure sand over coarser sand subsoil upon which are planted the largest and finest pineapple fields of the world; the sandy loams of various degrees of richness over subsoils of yellow sand, clay or marl, upon which are our magnificent citrus groves, famous melon, strawberry, and potato fields, Sea Island cotton, corn, and hay farms, and the coming pecan orchards. Then, to the south are the Everglade lands which are in a class to themselves, and their development is largely in the future. Since I confine my communications to actual facts, not hopes, -with the statement that marvelous crops have been made where there is a marl subsoil and drainage has been secured, I will drop the Everglades and go back to our various sandy loams. These are classed by their virgin growth which is influenced largely by water content.

The larger portion are pine lands,-—"high pine," "heavy pine," and "flat woods." The high pine is rather inclined to be thirsty, but is the site of many good groves, especially of grapefruit which is a rather better forager than the orange tree. The "spruce-pine ridges" are similar to the high pine land. The heavy pine is lower, richer soil, generally has undergrowth of saw palmetto and is intersected by strips of cabbage palmetto which indicate more moisture and by savannas growing only grass as proof that for a considerable part of the year 
the ground is saturated, thus preventing the growth of any shrubs or trees. Heavy pine is good for both groves and gardens. When these savannas are of large expanse they are called "prairies." Between the prairies and the pine land there is a state which induces the growth of hard wood and jungle-like vegetation. These tracts upon which are some of the finest citrus groves are called "hammocks." Hammock and prairie lands are exceedingly rich and produce the choicest of fruit and vegetables.

My readers must not think this is a standard classification. Every locality makes different distinctions, but I trust I have made it clear that the lands run from high, dry sand to low, wet soils rich in humus, and that the subsoil may be open or compact. Whichever land the prospective grower chooses he will find his choice brings with it both advantages and disadvantages.

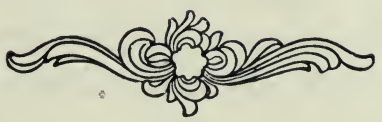




\section{Chapter II}

\section{Soil Preparation}

The clearing away of native growth should be done thoroughly; stumps and large roots occupy valuable space, interfere with cultivation, and furnish a breeding place for wood lice, etc.

Drainage-Good drainage is most essential. None of our commercial products do well on water-soaked soil. Open ditches are the most common means of drainage, but tiling is used quite extensively, especially in the sections devoted to intensive gardening. No rule can be laid down for this work as it must be governed entirely by local conditions. The point is to lower the water table so it is at least three feet below the surface. Wide, shallow ditches are much better than deep, narrow ones, as they are equally serviceable in wet seasons, and in dry seasons do not make the land on their border so droughty.

Plowing-Even the most enthusiastic advocates of deep plowing have found better results are obtained on heavier soil to make the first plowing shallow,-about three inches deep.

Lime-There are exceptions to all rules, but generally new land is sour, particularly after the broken roots commence to decay. Crushed limestone is the most natural and economical base we have at hand. The amount to be used depends upon the land; heavy land generally 
needs two or three tons to the acre, while one ton is often sufficient for light, open soil. If the clearing is too small to allow buying car lots of crushed limestone lyydrated lime can be used, but as this form is in much finer particles it acts more quickly and one ton per acre is the average application. The lime should be spread broadcast after plowing and harrowed in. This work is generally completed in the spring.

Cover Crops-Cowpeas, velvet beans, or beggar weed should be planted. In the fall, the cover crop should be mowed and dried. (Never turn under green vegetation.) Unless a disk plow is to be used for next plowing, thorough work should now be done with a disk harrow, cutting the vines and mixing them with the soil.

Second Plowing-A disk plow is best, but so far, few are used in the State. Very satisfactory results can be obtained with a good turn plow run as deep as the surface soil allows and followed in furrow with subsoil plow, each implement drawn by double team. Most of our soils crumble, but on heavy soils which hold their form the furrow should be thrown at a 45-degree angle.

Harrowing-The harrow should immediatély follow the plow to level the land that there be less exposed surface and to create a dust mulch to break capillary action. This conserves the moisture content. It is in the fall season now and our land is ready either for vegetables or trees, but in most cases the one comes out ahead who "makes haste slowly" and does not plant his trees until the second year. 


\section{Results Desired}

Since our lands are so varied and seasons are undependable, it is well for the grower to know just what are the results to be obtained by working the soil. The old idea of cultivating to kill weeds has long been cast aside. Land is cultivated to secure proper texture and the right content of air, water, and humus. These factors are dependent one upon the other, for no one of them would likely be correct without the others being about right also.

Texture-To be in perfect tilth, land must be a crumbly mass of soil grains, easily penetrated by feeding roots, admitting enough air but not too much, and holding a large amount of capillary water. The deeper in the soil this condition is maintained, the greater resources at the command of the plant. Vegetable growers and farmers should plow deep every fall, but the grovemaker must depend upon first preparation and constant attention to surface conditions. However, his trees are continuously on the ground and with their extensive root systems keep the underground right if given a chance for a good start. Working wet ground, especially in summer time, causes it to pack and sour. Often, the harm done by one ill-advised cultivation will show its effects for two or three years. Similar effects occur when particles are too fine,-so very fine there is practically no room for air or water in the soil. Such condition can be overcome by working when in right stage of mois- 
ture, especially if lime is added to induce "floceulation," - the gathering together of fine particles to make a soil grain. This trouble is found particularly among clay soils. Our new land is inclined to be too coarse and raw. No treatment can bring it into right texture immediately; it takes time and cultivation to accomplish this.

Air-Air in the soil is necessary for the respiration of the roots and the development of our friendly bacteria. It is also important in promoting chemical changes. Many of these are forms of oxidation and through them much plant food becomes available. This is especially noticeable in the formation of nitrates as taken up under "Bacteria." It will also be seen that the air supply deternines through its influence on bacteria, whether organic matter becomes plant food or plant poison. Too much air allows a drying-out of the soil, thereby decreasing the water supply of the plant.

Water-Capillary water is that held in films around the soil grains and is the ideal form of soil moisture. The smaller the soil grains the more surface they present, therefore, to a certain extent, the more water held by capillarity; and the more water in contact with the soil, the greater amount of plant food brought into availability. Free water, or ground water, is that which would run off if given a chance. It fills the spaces between the soil grains, thereby shutting out the air and bringing on the many troubles caused by such conditions. Such water should not be allowed within three feet of the surface. 
Humus-Humus increases the water storage by absorption and also by its particles being finer than the sand particles, which are the bulk of our soils. By holding the water it saves from leaching any plant food the water has in solution and also keeps the land from excessive heat in summer. It regulates the air supply, as it fills in coarse soils and opens up fine ones; it is a source of plant food, particularly of our most expensive element, nitrogen; and is both a food and a dwelling place for bacteria. The content of humus decides a soil's fertility. That there be no misunderstanding, I will explain: Vegetable matter, though popularly called humus, is not humus until properly decomposed; the peat-like substances found in some swamps, though of vegetable origin, are not humus and neither are they fertile. Humus is the fine dark dust of the soil; it is easily used by plants and much of it is drained away. The addition of humus matter to soil is necessary not alone for building up the soils but to preserve their natural fertility. The great crops we produce impoverish the land just as surely as drawing checks lessens a bank account. Right management of the soil makes the fertility greater each year. 


\section{Chapter III}

\section{Management of Different Soils}

The high, sand land is invaluable for pineapples since they demand an extremely open soil. However, the pineapple is a vigorous feeder and large quantities of organic fertilizers must be used and the soil kept free from crusted surface or weeds by frequent working with the scuffle hoe.

Light, Dry Land-The citrus grower, on high pine or spruce-pine lands, has no worry about drainage but must make a continuous struggle to conșerve moisture and to build up the humus content. The subsoil is likely to be open, tending to leaching; probably the lime has already been leached away. He should apply crushed limestone or hydrated lime for plant food and general soil conditions, but especially for a partial cementing of the soil particles at the "plow sole," thus making the drainage less rapid. Such land should be plowed at equal depth every year that the pressure of the plow make this plow sole. This plowing should be done in early spring and followed by shallow harrowing to keep a dust mulch over the surface. About the middle of May the summer application of fertilizer should be put on and cowpeas $\mathrm{or}^{\circ}$ velvet beans planted in drills so the cultivation can be continued until the rains come or until 
the vines cover the ground. In the fall, the vines should be mowed and when dry worked into the soil with a disk harrow. The fertilizers used for young trees and spring application on bearing trees should have an organic content. This should be of tankage or Peruvian guano-not cotton seed meal. By this method of cultivation the land will become heavier and darker and less thirsty every year, for the humus content will be increased. In starting young trees special attention should be paid to establishing a deep root system. With all these precautions, undoubtedly the difference in growth and fruit secured by irrigation would make an irrigation plant a most profitable investment.

Heavy, Wet Land-A direct opposite condition to the above is found in the groves where the water table comes within three feet of the surface. A natural growth of grass soon occurs on such land and this is allowed possession of the middles. Circles should be hoed around the trees and covered with heavy mulching. Strictly chemical fertilizers are adapted to this soil. They can be spread broadcast and left for the rains to carry down; there will be no waste. All the land will have to be worked for about three years after clearing to reduce the virgin growth and to secure right physical conditions, but great care must be taken not to puddle the soil by disturbing it when too wet, especially in hot weather. Such land invariably needs extensive drainage, and even then would be too wet during the summer rains were it not for the vast amount of water thrown off by 
the transpiration of the grass. Although the land is so wet during rainy seasons the trees soon feel the effects of a drouth, since the roots are necessarily so near the surface. To help toward conserving the moisture, when rains cease the grass should be mowed and left broadcast. By this, too, the natural humus content is kept up and all fertilizer used by the grass, the most important part of which (nitrates) would otherwise have leached away, is given back to the soil. Generally, irrigation is not used on these low lands, but some growers contend that the benefits gained in a dry season more than offset the expense.

I suppose someone is asking if the grass helps to evaporate the water from wet soils why does not the cover crop make the dry soil drier? The cover crop has not nearly so great a leaf surface as a heavy growth of grass; and, too, the grains of sand are such extremely good conductors of heat the ground would soon be hot enough to dry out the little soil moisture and to fairly burn the tender roots were it not.for the shade afforded. Many things in agriculture seem on the surface to be contradictory, but a little study makes the matter plain. Heavy applications of lime are almost sure to be needed on low, wet soils. Any convenient form can be used.

Other Soils-Between these two extremes of grove culture there are all gradations. Each grower must decide by actual results just what degree of cultivation applies best to his circumstances; texture of soil, humus, and moisture always receiving due consideration. 
Vegetables-Vegetables do not prosper on the lightest soils but the yields on our heary lands are almost incredible. Not alone one crop, but two or three can be produced over winter with a hay crop in summer from natural growth. Rich, sandy loams with heavy subsoil, are adapted to strawberries, melons, and Irish potatoes, while the pecan grove and diversified farming prosper best on the heaviest of loams with clay sulisoil.

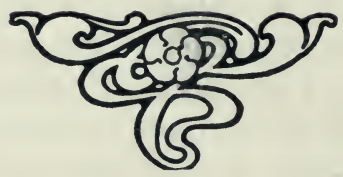




\section{Chapter IV}

\section{Lime}

We are all interested in lime as a base. Mest of our soils are acid and we wonder what form of lime to use, how much, and when to apply. All forms of free lime eventually revert to carbonate of lime, the form found in the original limestone.

Crushed Limestone-This, as the name signifies, is the natural limestone crushed. It is the best and most economical form to use on our sandy loams; best, because it is the nearest like a natural deposit; economical, because it has had no expensive preparation and can be sold cheap in bulk by car lots of fifteen or more tons. Two or three tons per acre is the usual application. Under ordinary conditions this amount will put the land in good growing condition and leave enough surplus to meet current demands for about four years. It has been estimated that the usual chemical reactions taking place in fertile soil cause a loss each year of about 500 pounds of lime per acre.

Quick, Caustic or "Rock" Lime-Rock lime is made by burning limestone. The carbon dioxide is driven out by intense heat. One hundred pounds of limestone make fifty-six pounds of rock lime which furnishes the same amount of base as the original one hundred pounds of 
limestone. Rock lime is sometimes used on extremely plastic (sticky) clay soils, but should not be applied to ordinary soils as its violent action burns out the humus.

Hydrated or Water=Slaked Lime-Hydrated lime is rock lime combined with about one-third its weight of water; therefore, seventy-four pounds are equal in basic qualities to fifty-six pounds of the rock lime or one hundred pounds of limestone. If, for the purpose of saving freight rock lime is purchased, it should be water-slaked before application. This can be done by putting it in piles of three or four bushels scattered over the field and covering the piles with four or five inches of damp earth. For best results, leave it for several days rather than to hasten the slaking by applying all the needed water at once. The best commercial hydrated lime comes in 40-1b. paper bags. It is put up in this way to prevent air-slaking. About one ton of hydrated lime is used per acre. It acts more readily than crushed limestone because of its particles being so much finer, but though the ton application may give as good results the first year as a three-ton application of crushed limestone, its effects on the land will be seen less than half as long.

Air=Slaked or Carbonate of Lime-As said above, all forms of free lime eventually revert to carbonate of lime. If rock and hydrated lime are exposed to the air they gradually take on carbon dioxide until fully combined. Air-slaked lime is exactly the same chemically as limestone and has the same value as base; however, its physi- 
cal form being so much finer, allows quicker action and the general application of air-slaked lime is about a ton per acre, thus another application will be needed much sconer than when crushed limestone is used. The economical buyer does not purchase air-slaked lime, for it costs as much per ton as the hydrated and the same freight, yet it is really worth only three-fourths as much.

Miscellaneous Forms-Sulphate of lime, gypsum, or land plaster, is not a base but is most valuable in in. ducing chemical changes that bring latent plant food (potash in particular) into availability. Superphosphate and dissolved boneblack are about two-thirds sulphate of lime, and one-third phosphate of lime. Sulphate of lime combines with free ammonia, fixing it as sulphate of ammonia. Unleached wood ashes contain about 35 per cent. carbonate of lime, and Basic Slag is popularly believed to carry about $33 \frac{1}{3}$ per cent. of free lime, but Dr. Van Slyke, Chemist of the Agricultural Experiment Station of New York, says that though there is about a 35 per cent. content of calcium, "generally less than two and often less than one per cent. is present as calcium oxide or so-called free lime, while the amount of carbonate is insignificant."

Free lime must not be mixed with fertilizer, as it causes a waste of ammonia. Lime should not be used on Irish potato land; it makes conditions favorable for scab. Lime around cabbage, etc., keeps down club root, and on sweet potato ground has been found most effective in reducing soil rot of sweet potatoes. 
When to Apply-When land needs liming, the best time to put the lime on is as soon as the labor can be secured if it is at least three or four weeks before an application of fertilizer or two weeks after. With this precaution, land can be limed at any time convenient to the grower; however, when it can be so arranged, probably early August is the most desirable time for application, as the summer fertilizer is well incorporated with the soil so there will be no waste through contact of fertilizer and lime on surface of ground, and the nitrates formed will be taken up by the cover crop and the September growth of the trees.

Too Much Lime?-Too great alkalinity is detrimental, but the dangerous alkali salts are based "mainly on soda with a small content of potash and usually a little lime and magnesia." Black alkali is mainly carbonate of soda, while white alkali, which is less injurious, is principally sulphate of soda. With our bounteous rainfall and open soil there is not the least danger of our forming an "alkali desert" by any applications we might make. The soda left from nitrate of soda is beneficial to us, not detrimental. In clay lands where. nitrate of soda is used in excess it packs the soil, but only in arid regions does "alkali" accumulate. As against "alkali," note the limestone regions. It is proverbial that "a limestone country is a rich country." Imagine any application of limestone approaching the amount of these natural deposits! 
At the recent citrus seminar Mr. Collison, Chemist of the Agricultural Experiment Station, who is making a particular study of soil chemistry and fertilizers, made the statement that though he could not give the maximum amount of crushed limestone which might be applied without harm "ten tons per acre dir not approach the danger line." Both Professor Rolfs, Director, and Captain Rose, State Chemist, two men eminently fitted by education and wide experience to pass upon Florida conditions, agreed to his statement. Dean Vernon, of the College of Agriculture, Dr. Flint, Chemist, and Major Floyd, Horticulturist of the University of Florida, and many other scientists, as well as our oldest and most successful growers say we do not use near enough lime and that there is no probability of there being too much crushed limestone applied to the general Florida soil. Hopkins, of the Illinois Agricultural Experiment Station, mentions a ten-ton per acre application as likely to be beneficial rather than detrimental, while Hilgard, King, Bailey, Van Slyke, and in fact, all agricultural chemists, emphasize the value of plenty of base "preferably carbonate of lime." With this unanimity of all real authorities I think we may rest easy about the question of too much lime, especially as none of us are going to use even five tons per acre. It is to be hoped, though, that the application of two or three tons per acre of crushed limestone followed every four years by at least another ton is going to become general, as our lands need this much base. 


\section{Other Uses of Lime}

Lime is one of the essentials of plant growth. It is used to strengthen the cell walls, and with potash, aids in the moving of organized plant foods-starch, sugar, etc.,-within the plant. The word "organized" is used in this instance to distinguish the "digested" sap or combined substances from the "raw" sap, or separate elements. Van Slyke, in his extensive study of the relation of lime to plant growth, found lime to be most abundant where there was the greatest activity; that "leaves use over fifteen times as much as fruit;" and that the least lime is found where "manufactured foods are stored and in dead parts such as old wood." Without doubt, more lime is used as a direct plant food than is generally supposed, and it also has decidedly beneficial effects on soil texture.

Lime makes clay soils more open and sandy soils more compact. It aids in the decomposition of organic matter through creating conditions favorable for the rapid multiplication of bacteria. It, in a measure, replaces potash in unavailable soil compounds and often induces a union with the phosphoric acid of insoluble iron phosphates, thus bringing both potash and phosphoric acid into availability.

Because of this soil exhaustion it used to be said that lime made "rich fathers and poor sons," but we now have learned to reap the good and avoid the evil. 


\section{Conservation of Soil}

While every effort should be made to induce bacterial and chemical activity because of the effects upon the general condition of the soil it must be remembered that if a plant uses the released plant foods and is taken away, or if the soluble plant foods are lost in the drainage waters, the land has given up just so much of its resources. The wise manager keeps up or adds to the natural humus content and applies the mineral elements in the form of commercial fertilizers to replace more than the amount used by the plant. He fertilizes his crop, not the soil, giving extra amounts of the essential especially lacking, thus providing certainly available nourishment for his plants and constantly building up a more fertile and better balanced soil.

In relation to the plant, soil should not be considered as a.pasture through which rootlets may pick their way, gathering a morsel here and there, but instead, as a comfortable environment providing shelter and abundant supplies. In relation to its owner, soil should be considered as a bank. It is not how much we can get out of the soil that affects our prosperity, but how much we put in. The better the soil, the better the crops that can be made from it, so the grower should always leave a little more than he takes. The immediate profit should come from the plants, which, if managed right, give us so much for the little they take. In no way is the world. noted "American Improvidence" shown more forcibly than in the widespread inattention to soil conservation and upbuilding. 


\section{Chapter V \\ Starting the Grove}

For the benefit of those who may not have read the foregoing carefully I will indulge in a little recapitulation.

Clear the land thoroughly; old stumps are in the way of cultivation, create more or less acidity and invite wood lice, which, at any time may conclude that they prefer to live upon the tender young citrus trees.

Drainage is essential. There is absolutely no use in trying to raise a profitable grove on water-soaked land. Where Nature has not furnished this drainage, provide for it before planting the trees. On such land as this the grower reaps the greatest benefit from raising a crop of cowpeas or velvet beans before setting his grove.

Liming the land will in almost every instance prove a good investment and in most cases is really necessary for profitable results. An application of two or three tons per acre of crushed limestone is a most economical and satisfactory way to meet this requirement. The exceptions to needing lime would be in some limestone regions and where there is a marl subsoil about a foot below the surface. In such cases Nature has already supplied the lime.

What to Plant-A grapefruit tree bears younger than an orange tree, and since each fruit is so much larger, 
the number of boxes is greatly increased when equal numbers of fruit are borne. Much of the time grapefruit sells for more per box. The prospective grower at first thinks there can be no question as to his preference,-quicker returns on investment, less cost per box for production, higher market,-all in favor of grapefruit. Then he learns that many others have come to the same decision, and that at the present time there are hundreds of acres more grapefruit than oranges not yet in bearing. He considers that though grapefruit is so popular as a breakfast food and the demand for it is so deservedly increasing, nothing will ever appeal to the human family like the orange,-oranges for breakfast, dinner, and supper and between meals, nothing more healthful or more appetizing,-and he will wisely decide to have both of these delicious fruits.

Varieties-There are a bewildering number of varieties, each with good points, but for strictly financial investment the choice rests with a few. I think however enthusiastic anyone may be over some particular fruit, all experienced growers will agree that the greater number of successes have been made from the varieties named below.

The Duncan grapefruit is oblate in form, of medium size, attractive in appearance and of fine flavor. It bears freely but not in such close clusters as to mar the fruit. It is desirable in every way.

The Parson Brown is an orange medium to large in size, yellow in color, sometimes with orange tinge, rind 
smooth and bright. It is matured in October and November and if it is not gathered soon, loses its flavor. Often, the fruit will be ripe and sweet when the rind is still green.

The Pineapple orange is oval to round in shape, of medium to large size, has deep rich orange color, often with reddish tinge. The rind is most attractive, being very bright, smooth and glossy. The juice is abundant and of exceptionally good flavor. Its season is about January or February, but it can be held later. The new groves set by old growers show a very large percentage of this variety.

The Valencia Late and Hart's Late are so near alike their best friends make little or no distinction between them. They are round or slightly oval in form, medium to large in size, of deep golden color, with thin, smooth, tough rind. They are very juicy and have a rich flavor with such a combination of acidity and sweetness as to be especially pleasing during the spring months,-March to June,-when they are in season.

The Dancy tangerine is the most satisfactory orange of the Mandarin family. It is oblate in form, medium size, deep orange red, smooth, shiny rind which is easily removed; its sections separate readily and the flesh is dark orange in color, coarse grained, juicy, and has scarcely any rag. Flavor is rich, season December and January.

Special favorites are generally planted for home pleasure. The King of the Mandarin family is as delicious 
as its exterior is unattractive. The Ruby Blood is most luscious and is especially interesting because its flesh is first yellow, then streaked with red and finally becomes blood red when fully ripe. The Washington Navel is also a novelty because of the secondary orange in the blossom end, giving it the havel-like appearance, and is delicious to the taste. Many other varieties have some specially good points but are in some way not desirable as commercial propositions.

Stock-The sour orange stock has proved itself best adapted to all kinds of soil and most resistant to diseases. It is almost immune to foot rot so prevalent on sweet orange or rough lemon stock. Grapefruit stock promises well and is highly favored by many, but it has not been so thoroughly tested as the sour orange. It roots extremely deep and is best suited to our higher lands. So far there has not been shown to be any difference between grapefruit and sour orange stock as to vigor of trees or quality of fruit.

Size-There is a difference in opinion as to the best age of trees set. To the investor who has plenty of capital it is a great temptation to pay a higher price and get a nice, big tree with a two-year-old bud, but it has been the experience of the greater number that a twoor three-year-old stock with a one-year-old bud stands transplanting better than the older trees, and when put side by side will be larger and thriftier two years after setting.

Nursery stock should be neither forced nor stunted 
and should be grown on a lighter, drier soil than in the proposed grove rather than on heavier, wetter land.

When to Set Trees-The best time to set trees is from the middle of November to the middle of February, though with proper handling it is safe to move an orange tree at almost any time. Trees must be kept damp from the taking-up until they are set in the ground. Many a tree gets its death stroke between the nursery and the grove, though it may struggle along some months before it finally succumbs.

Pruning-Do not make the mistake of trying to keep too much top. The top should be cut off about one and a half or two feet above the ground. The roots should be cut to about a foot in length, with the tap root about one and a half feet. The ends should be cut smooth, not broken or crushed.

Distance-There are many opinions in regard to what is the most profitable space for a tree. My personal preference is to have orange trees twenty, and grapefruit trees twenty-five feet apart in rows thirty feet wide. When well grown the branches will meet in the rows, but a team can pass between the rows. For economy and effectiveness of labor, it is necessary to use teams, which would be impossible in groves set much closer than this. The closely set groves yield a much greater income the first few years at least. Their advocates say they continue to do so, but all the owners of old closely set groves I have seen, wish they had more space. Many prospective growers have it figured out on paper that 
they could afford to cut down every other tree when the grove is eight or ten years old, but unfortunately, the profits on citrus culture show to just the same advantage on paper as compared with real practice as do the profits on any other kind of business. The man who said "figures don't lie" never figured out any financial proposition dependent upon labor and climatic conditions, and then tried to make actual practice match his figures.

Final Preparation-Low ground should be plowed into beds the width of the rows before setting the stakes to mark places for the trees. Shallow cultivation should immediately follow the plowing and be repeated after every rain. The land should be left to settle at least a month before planting. If some hard rains come, so much the better. Care should be taken to set the stakes exact,-in straight rows and equal distance apart. Around each stake spread a peck of hardwood ashes. When the hole is lug the ashes will become thoroughly mixed with the soil.

Holes-Pull the dirt from around the stake with a hoe, leaving the ground in the shape of an inverted saucer, the bottom edge being a foot deep. Drive a stake in the ground to make a hole for the tap root.

Setting the Trees-Place the tree in the hole and spread the roots evenly. If a root is longer than the width of the hole allows do not pinch off the end or turn it to one side, as so many do, but dig out a place for it to extend full length in a natural position. Set the tree an inch higher than it was in the nursery as it 
will settle some, and a tree set too low never prospers. Pull part of the dirt over the roots and pour in a bucket of water, holding the bucket at least two feet above the ground so the water will fall with force. Pull more dirt around the trees and pack tightly, mounding up a little in the shape of a saucer. Pour on another bucket of water and then mulch with dry dirt to prevent evaporation. There should be no delay in the work from the time the dirt is first disturbed until the mulching is in place, thus preserving the natural moisture of the soil.

Care-The trees will need no further attention for several weeks unless the season is especially dry, in which case water should be given very sparingly until the rains come. The dry mulch should be replaced each time the trees are watered. Too much water will cause the soil to sour and give the trees a serious setback.

Fertilizer-It will be noted that I advise no fertilizer at time of planting. About the first of February, or when the new growth starts, give each tree a pound of a formula carrying about five per cent. of ammonia, six per cent. phosphoric acid and five per cent. potash, derived from nitrate of soda, sulphate of ammonia, tankage or Peruvian guano, superphosphate or dissolved boneblack and sulphate of potash ; or, if the land is especially low and heavy, use a strictly chemical formula carrying less ammonia and more potash,- -about a 4-6-8 analysis.

In June and September two more applications of one pound of fertilizer can be made. The second year the trees should use two pounds of fertilizer at each appli- 
cation, and the third year three pounds. After this the amount can be rapidly increased if the trees are doing well, for the fourth year should find them com. mencing to bear fruit.

Training-Generally speaking, the citrus tree knows better how it wants to grow than does the one who interferes with its development. It does not hurt it to bear fruit young, as is the case with many other fruit trees. All sprouts below the bud should be rubbed off, but the sprouts above the bud should be left unless they seem especially crowded, in which case it will be best to pinch off the tops of some of the shoots. After the trees get well started they may need "shaping up" a little, but no extensive pruning should be done. Dead wood is a great source of infection; if any occurs it should be removed, the cut being made back to an elbow and left a smooth slant.

Cultivation-Young trees should be hoed deep so as to make the roots strike down. The middles can be plowed in spring. Cultivation should be kept up all through the dry season to conserve moisture. When the summer rains commence the ground should be covered either with natural growth of grass or weeds or a planted cover crop. My personal choice of cover crops would be cowpeas. This growth must not be allowed to "smother" the roots of the trees. There should be a heavy mulch of dead vegetation for at least three feet from the trunk. This mulch must not touch the trunk of the tree or wood lice will be likely to nest there. When the weather gets 
cool the mulching should be drawn away to allow all the warmth possible to reach the young roots. The cover crop can either be allowed to die down naturally as the season is over or be mowed and left broadcast to be disked in before next plowing. Never work the soil when saturated with water or during the heat of summer, and never plow in green vegetation. These are three causes for acid soils.

Insects and Diseases-If the above precautions are taken in the preparation of land and its cultivation there will likely be no diseases affecting the young trees, as the troubles of young citrus trees are almost invariably due to lack of care, but they must be watched closely for insects. Sometimes ants or grasshoppers eat part of the foliage and occasionally there will be found a great ugly worm called the "orange dog" which is a voracious eater and makes a young tree look ragged in a short time, but none of these troubles are likely to be of any great moment.

The nests of the ants should be broken up by making holes into them by thrusting down a pointed stick and into each hole pouring a tablespoonful of bisulphide of carbon (which is very inflammable), covering each hole immediately with tightly packed earth. Grasshoppers can be killed by scattering around the trees bait made as follows: One part Paris green, two parts salt, forty parts horse manure by measure, and water sufficient to make it soft without being sloppy. Grasshoppers show 
a great fondness for moist horse manure. Orange dogs must be hand picked.

The serious pest of young trees is the scale. Procure a lens and examine any roughness found on trunk, twigs or leaves. If whitefly is in your section that must be controlled also. Luckily the same spray is effective for both whitefly and scale, but the spray must be directed to the infested areas. Whitefly lives on the under side of the leaves; scales are anywhere they happen to settle, but are generally more numerous on the trunk and branches. Both are sucking insects and must be killed with contact insecticides. Yothers' Formula No. 3 is the best mixture for this purpose known at the present time, as it not only kills all the insects it hits but remains on the trees several weeks in sufficient strength to kill newly hatched larvae. It is made as follows: Three measures Diamond Paraffine Oil, two of whale-oil soap and one of water. While rapidly beating the soap add the oil, a few drops at a time. It should form a creamy emulsion. Gradually add the water as the beating is continued. Test for perfect emulsion by putting a little in a glass of water. If free oil forms on the surface the mixture must be beaten longer and perhaps a little more soap added. When thoroughly emulsified use one part of this stock solution to fifty parts of water. To have the greatest effect spraying should be done soon after the young are hatched.

Criticisms-The above is not the only way to set a grove. Probably there is not a citrus grower in the State 
but would differ from me in some particular; but I have given what is a safe method for the inexperienced grovemaker to follow. I would ask those who specially differ to put the method they would propose to these two tests: Would it suit general conditions, or is it specially adapted to one particular locality? Could a person entirely unacquainted with the nature of the citrus tree successfully carry out the plan, or does it require the judgment gained only from years of experience? An experienced citrus grower can safely push young trees much faster than a novice should attempt.

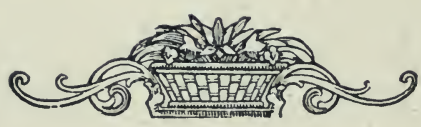




\section{Chapter $\mathrm{V} I$ \\ What a Fertilizer Tag Means}

Captain Rose, our efficient State Chemist, says: "A fertilizer tag is intended to mean just what it says-how many pounds of valuable plant food are contained in the package, and what materials are used in its manufacture." This is the kernel of the nut. The fertilizer tag means what it says, not what it implies. The wording below is taken from a model tag.
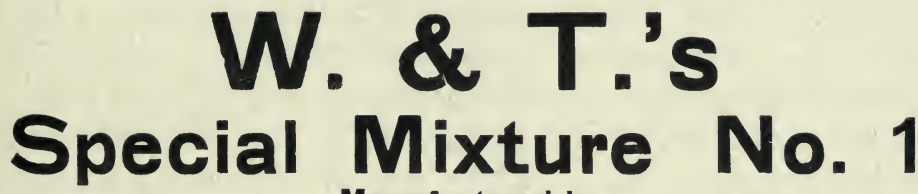

Manufactured by

Wilson \& Toomer Fertilizer Co. Manufacturers of the Celebrated "IDEAL. FERTILIZERS"

\section{GUARANTEED ANALYSIS}

Moisture at 212 degrees Fahrenheit, not exceeding ....... 8 per cent. Available Phosphoric Acid, not less than .............6 per cent. Insoluble Phosphoric Acid, not less than ............. 1 per cent. Ammonia, actual and potential, not less than .......... 5 per cent.

(Derived from Sulphate of Ammonia. Nitrate of Soda and Tankage)

Potash (K20) Water Soluble, not less than .............5 per cent.

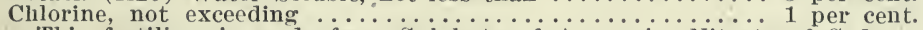
This fertilizer is made from Sulphate of Ammonia, Nitrate of Soda, Tankage, Superphosphate, and Sulphate of Potash.

It is well to pay attention to the brand name. Each fertilizer company sends out many different formulas 
suited to different purposes and the brand name is a short, simple way to give full description of the exact formula. It means certain proportions of certain materials as shown on the tag attached to the fertilizer sack.

The name of the manufacturers means just what they have made it mean. Like all classes of people, some naturally want to give their customers a fair deal, others see the policy in doing so, while others skim just as near to the edge of the law as they dare. Florida is to be congratulated on the high standard maintained by her fertilizer people and on the means she has taken to protect honest manufacturers and the consumers, but it is not alone honesty that determines the value of the manufacturer's name. Analysis and sources determine the market value of fertilizer, but the practical value is largely influenced by proportions and combinations. Some manufacturers are keener than others to see just what gives best results or will work harder to bring those results about. The personal factor has the - same influence in the fertilizer business as in everything else.

The number of pounds tells the amount put into the sack at the time of filling.

The guaranteed analysis tells the amount of actual plant food, the moisture content as an indicator of physical condition, and the chlorine content to protect the grower of such crops as are harmed by chlorine.

The fertilizer is sold on the basis of its actual content of phosphoric acid, ammonia and potash. Six per cent. 
of phosphoric acid means that six pounds of the actual phosphoric acid are in every hundred pounds of fertilizer, or 120 pounds in every ton. When the grower first looks into this he is likely to reckon up the actual plant food, which on the above tag would amount to 340 pounds and begin to talk about 1660 pounds filler. He will "buy his fertilizer materials and mix them himself before he will pay for so much sand!" But when he begins to figure on these fertilizer materials he finds that to get the 120 pounds phosphoric acid he must buy 750 pounds superphosphate, that his sources of ammonia run from $6 \frac{1}{2}$ to 25 per cent., and that high-grade sulphate of potash carries only 49 per cent. actual plant food. In fact, that the materials necessary to supply this analysis easily make up the 2000 pounds.

The buyer should note whether the term "Available Phosphoric Acid" is used and not accept a guarantee of "Phosphoric Acid" or "Total Phosphoric Acid" alone unless the source is of an organic nature,-tankage, bone, guano, etc. One exception to this rule would be in the case of Thomas Phosphate Powder, as it is always sold under guarantee of total phosphoric acid, but this material is seldom used in formulas. After taking this precaution, he can be assured he is getting all the plant food represented for "woe be unto" the manufacturer giving short measure. Captain Rose and his inspectors would catch up with him before he got well started in such methods.

But in the last paragraph there are sometimes pitfalls 
for the unwary. You will note on this model tag there is a distinct statement in regard to the materials used. It gives definite information. If in addition to this statement there were the words "and other ingredients" the whole guarantee of its sources would be practically broken down, for any of the sources named could be used in small quantities and any "other ingredients" suited to the manufacturer's convenience could be used. It would be possible under this wording to supply a largely organic fertilizer under seemingly purely chemical representation, or vice versa. Or again, if in place of "tankage" the words "organic matter" were used, that organic matter could be tankage or guano to be sure, but it also could be any organic material supplying available ammonia, from treated garbage or leather and wool waste to all forms of vegetable matter,-cotton seed meal, castor meal, etc. The tag "means what it says."

But what is back of the tag? Not only the manufacturer but the State. Our fertilizer law is very strict and closely followed up by the State officials. Inspectors are constantly over the State, drawing samples from fertilizers offered for sale. Any sack of fertilizer sent out, even to the most remote flag station, is likely to come within their investigations. Besides this there is a provision for "Special Samples" which can be drawn by the consumer and sent to the State Laboratory for analysis free of cost. To protect the manufacturer there are certain rules and regulations (sent by the Department of Agriculture, Tallahassee), under which this sample 
must be drawn, but they are easy to follow and there is no excuse for the buyer to be in doubt as to whether he is getting a "square deal." Florida is the only State giving her citizens this protection which is equally valuable to manufacturers and consumers.

Who pays for this inspection? The manufacturer primarily, as he buys the stamps and affixes them, but eventually the consumer, as in everything else. The cost is very slight per ton,-only twenty-five cents,-but since 183,437.84 tons of commercial fertilizer were used in the State in 1911 the aggregate of stamp sales for fertilizer was the tidy sum of $\$ 45,859.46$.

In Captain Rose's Report for 1909, he shows that under this law which was first enforced in 1901, the goods put upon the market increased in actual value more than ten per cent., many unreliable brands being driven from the State. In the year 1909 this ten per cent. of the selling price of fertilizer together with feeds, which are protected in the same way, amounted to $\$ 657,840$. That is, the consumers of fertilizers and feeds in Florida were given $\$ 657,840$ more for their money than they would have received had the law not been enacted. The stamps for this year cost the consumers $\$ 56,792$, leaving over $\$ 600,000$ clear gain in a single year.

The sale of inspection stamps for fertilizer and feed in 1912 amounted to $\$ \$ 2,820.55$ and the inspection cost the State $\$ 15,257.41$, leaving a credit to the General Revenue Fund of $\$ 67,563.14$. 
The agriculturist pays this in the main, for he uses all fertilizer and the greater share of the feed. Yet with all this surplus he is very modest in his demands upon the State Funds.

He needs to have his workers at the State Experiment Station better paid, so that other States cannot take them from us when they reach the point where they can be of greatest service. He needs more funds to print matter that has been compiled for his benefit,-matter of untold value to him that is lying in manuscript inactive upon the shelves. He needs more workers, for there are problems of immense economic value that are unconsidered for lack of men. He needs more Farmers' Institutes, a yeariy demonstration train, support for the Horticultural Society that is, and the Agricultural and Live Stock Societies that ought to be. He needs the work of nursery inspection enlarged and a horticultural law suiting our conditions gradually built up and enforced. He needs, - oh, there is no use trying to tell all the ways the grower could use his own money to advantage since he is willing to let other folks use it for him. I am no politician, but even I wonder at our energetic talk about laws, the apathy we show in getting them enacted, and the utter disregard we have of any provision for enforcing them if they are passed. See, this trait is in us all, but I am going back to fertilizers. 


\section{Chapter VII \\ Home Mixing}

Te were speaking of the grower considering the matter of mixing his own fertilizer. Personally, I place home mixing of fertilizers on the same level as making one's own furniture, tools, clothes, sugar, soap, etc. In the twenty-one years I lived on the farm here in Florida there was no "home mixing" or "special mixtures" used or even straighto chemicals with the exception of a little nitrate of soda. I always did believe in taking all I could get for nothing. When I can get the experience of many people for many years and all the excellence of expert work for no addition on cost of material, I take it.

Aside from the trouble that may come from improper combinations and proportions, chemical analyses show that even though home mixing be done according to the best directions, the results are far from uniform;- that labor with the equipment of the farm cannot compete with the efficiency of a modern factory. H. C. Moore of Atlanta, Ga., has given this subject an extensive study. His compilation of analyses from crude mixing facilities is most interesting. For instance, four different samples of a should-be 9-2-3 formula run from 8.18 to 15.35 per cent. available phosphoric acid, from .56 to 2.89 per cent. ammonia, and from .43 to 3.27 per cent. of 
potash. We can only imagine what a great number of samples would have shown. He rightly says "A planter surely cannot expect to get uniform results from application of such poorly mixed fertilizers."

He calls up a further point, that fertilizer materials have such different weights they do not stay mixed unless properly ground and combined together. He gives the weight per cubic foot of some of the most common materials as follows: Superphosphate, $60 \mathrm{lbs}$; blood, $30 \mathrm{lbs}$; tankage, $45 \mathrm{lbs}$; nitrate of soda, $85 \mathrm{lbs}$; sulphate of ammonia, 55 lbs.; sulphate of potash, 80 lbs. When merely mixed the heavier materials gradually settle toward the bottom.

It is best for all users of fertilizers to learn all they can about different fertilizer materials, and I will go into detail on that subject later, but such knowledge is necessary far more for the purpose of selecting proper formulas than for the creating of formulas, for when the different materials are mixed together their action on each other must be considered as well as upon the plant and the soil.

To my mind, there could not be a better argument for mixed formulas than the tank experiments carried on at Gainesville. From them we find a great waste of nitrates-greater by far when nitrate of soda was used, but alarming even from sulphate of ammonia. Both for the prosperity of the plant and for economy, it is a feasible conclusion that a gradually available supply is better than any one particular source. An exception 
to this would be in formulas carrying low content of ammonia, especially in cool weather when bacterial action is slower, but generally speaking, I would choose two or three sources of ammonia.

Who knows just how much of these sources should be used to guard against starving periods and waste? Some men in the State can watch their crops and tell from time to time just what plant food they need, and from this experience can order special mixtures suited to their needs, but they are few. Some citrus growers prefer to feed their trees "piece meal" as it might be called, - a little nitrate of soda now, or perhaps some sulphate of ammonia, some dissolved boneblack cr superphosphate later, and at another time some sulphate of potash. Some of the finest of groves are fertilized in this way, but they are not one bit finer than some other groves that never have had anything but straight commercial formulas, and the men have had a great deal of unnecessary thought and execution. My contention is not at all that no grower knows how to feed his crops, but that only a few have given the matter sufficient attention to get the best results in this way and that these few could turn their time to better use financially. If, as is the case with many, the work is a matter of pleasure, that alters the matter entirely. Besides enjoying himself, such a man adds to the State's assets, for the greater number of the most successful commercial formulas come from just such origin and the one who buys them has the benefit of the other man's work. But I write to the 
great majority,- those who are particularly interested in the financial side of the matter. They do not have time or inclination to become experts in the use of plant food and to attain the greatest financial success should be as ready to secure the benefits of expert fertilizer production as to use the product of other manufacturers.

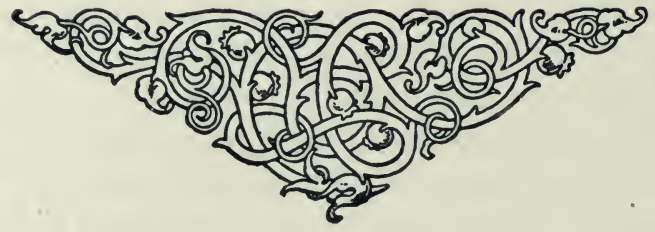




\section{Chapter VIII}

\section{Effect of the Different Elements}

All forms of nitrogen are legally reckoned as ammonia, phosphorus as phosphoric acid, and potassium as potash. I fear an account of the exact difference in these forms would be tedious, so in speaking of these elements I will simply call them by their trade names and not make nice distinctions for the sake of being chemically exact.

Ammonia promotes growth; phosphoric acid, general development and fruiting, and potash hardens the plant and gives to the fruit color, flavor and firmness of texture. All three are important in all plant functions, either being a constituent of or intimately associated with the protoplasm, which is the jelly-like substance just within the cell walls - the real living part of the plant.

Ammonia forms about sixteen per cent. of the protoplasm and "regulates the growth of the whole plant," while "without phosphorus, protoplasm could not exist," and potash influenecs the "formation and activity of protoplasm."

Ammonia is also a "prominent constituent of chlorophyl,"-the substance which gives the green color to plants, and which is so active in the "digestion" of plant food elements. 
Phosphoric Acid acts particularly as a catalyzer or digestor of other compounds, and in connection with potash, magnesia and lime acts in the translocation of plant food. Phosphoric acid is especially essential in seed development and by this action tends to early maturing of fruit.

Potash and lime give strength to cell walls. Potash is necessary in the formation of starch, sugar, and cellulose,-the fibrous part of plants,-though it is not a constituent of these compounds; and it is potash which gives the tartness so desirable in all fruit to relieve in. sipidity. Potash is needed for the development of flesh on "fleshy" fruits and to give this flesh "good shipping qualities."

Proportions-So long as right proportions are maintained, the plant will develop properly however much (within reason) plant food it has at hand, but unbalanced proportions are detrimental.

Too great a proportion of nitrogen makes the growth soft and flabby and very susceptible to disease. Too little limits all activity,-growth of plant, blooming, or development of fruit, - and is likely to show especially in small leaves and "off color," either a pale green or a more or less deep tinge of yellow.

Too great a proportion of phosphoric acid makes the leaves small, profuse bloom, and the fruit mature while yet undersized. Too little shows in the "mottled leaf," scant blooming, and lack of general vigor and development. 
Too great a proportion of potash makes small foliage and hard, brittle wood, and checks prolificness. Too little leaves the plant and fruit soft in texture, therefore susceptible to disease and decay, limits the starch or sugar content and causes a lack of any high color which may be natural to the fruit.

Lime is used as mentioned above in strengthening the cell walls and translocation of plant food, for which it is most essential, but its greatest effect upon the plant is indirectly through establishing good soil conditions. We have already taken that up except that the presence of lime causes a profuse development of root hairs which increases the plant's power to feed.

Magnesia is closely associated with lime. It is one of the plant essentials, yet it is actually noxious to plants even in small quantities unless accompanied by lime in a ratio of about $2: 1$. Magnesia is important in the development of seed, acts with the protoplasm in assimilating phosphates, and is a constituent of chlorophyl. Those who wish to study this element further should send to United States Dept. of Agriculture, Washington, D. C., for Bulletin No. 1, Bureau of Plant Industry : "The Relation of Lime and Magnesia to Plant Growth."

Sulphur is a constituent of the protoplasm and also of plant protein,--that is the nitrogenous compounds. "Its action is important," many plants using more sulphur than phosphorus.

Iron is necessary for formation of chlorophyl, though no iron compound is found in either protoplasm or chlo- 
rophyl. It is highly important, but used in such infinitesimal quantities Nature always has sufficient available iron at hand. Van Slyke says: "No direct evidence has yet been furnished to show that the application of iron compounds has any beneficial effect on either color or yield of fruit."

Chlorine and Sodium are not essentials to plant life, but are invariably found in the plant. Beyond a certain amount they are harmful, some crops being much more sensitive to their effects than others. These two elements combined form our common salt.

Manganese is not an essential and is of so little importance many authorities do not mention its connection with plant life, though a trace of it is generally found in all plants. In certain parts of the world (where lava abounds) it has been studied because its presence has so bad an effect on plants. It destroys the chlorophyl, disturbs the balance of other elements, especially decreasing the assimilation of phosphoric acid, interferes with formation of protoplasm, etc. This is fully explained in Bulletin No. 26, Hawaii Agricultural Experiment Station: "The Function and Distribution of Manganese in Plants and Soils." This bulletin can be obtained from United States Dept. of Agricultrere, Washington, D. C., but I can assure all that they need neither endeavor to build up the manganese content of their soil nor fear they will get too much manganese here in Florida.

Fads come and go,--only our real needs endure. A 
few years ago there was much talk about iron; now it is scarcely mentioned, but some of us are almost wondering how we ever grew any crops at all when so ignorant of magnesia and manganese! The fact is, we do not want manganese, and though our soils are low in both lime and magnesia content, the low-grade sulphate of potash which carries two-thirds as much sulphate of magnesia as sulphate of potash, has supplied any needed magnesia, while the sulphate of lime in superphosphate and dissolved boneback has kept up the proper ratio of lime for plant food. It is not necessary that the lime for this purpose be basic. Properly mixed formulas supply all such needs. When people study the subject thoroughly they appreciate what one man said: "The man who knows enough to mix his own formulas knows enough not to."

Common Sense is as effective in the field as in the home. Nature furnishes easy ways to preserve her balance and it is only when man interferes too much that trouble comes. Did our plants have to depend upon our supplying the exact amounts of everything necessary, they would be in as bad a fix as the people who continually try so-called scientific diets.

Practice has shown that on our table we should have reasonable proportions of meat and vegetables, sweets and fats, and that in our fields, crops prosper when available ammonia, phosphoric acid and potash are added in proper proportions. In the carriers of these essentials and in the air and the soil are all other essentials, 
and the protoplasm, that living substance within the cell walls, is going to use them as the need occurs. The grower sometimes rebels at getting only (for instance) sixteen pounds of plant food in a hundred pounds of material, but often in that other eighty-four pounds he gets the rery thing that he would have.missed applying had it all been left to him, and perhaps it is a most important factor in his success. What is, is generally about right. Only a few of us could really improve (?) upon conditions were they all within our control.

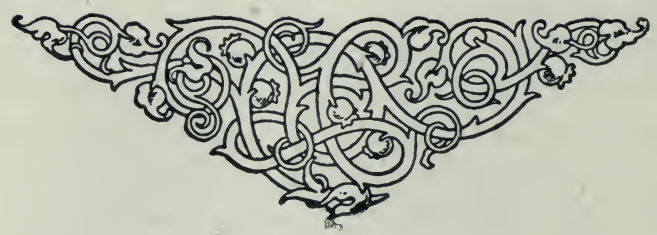




\section{Chapter IX \\ Fertilizer Materials}

Peruvian Guano carries ammonia, phosphoric acid, potash, and lime, which are readily but gradually available. It is of organic origin but so old and thoroughly decomposed it forms no acid by-products. It is a great soil builder and a valuable material for the use of those who want untreated materials of alkaline tendency. Peruvian guano carries about fourteen per cent. lime, which is soon left basic, being in organic compounds.

Sulphate of Ammonia is inorganic. It is the best gradually available source of ammonia the citrus grower has at his command, and is equally valuable to truckers and other users of fertilizer as a source between nitrates and organic matter. It tends to soil acidity, which can be corrected by using lime. As sulphate of ammonia is used in mixed formulas, its acid tendency is balanced by the alkaline tendency of nitrate of soda.

Nitrate of Soda is inorganic, carrying ammonia in a form available to plants, therefore is ready as soon as it is dissolved. It dissolves in an equal part of water, thus will be active when no other fertilizer material could reach the plant. It has an alkaline tendency. Loss of nitrates is serious unless there is such supply as to allow the plant to use them before they sink beyond reach of the roots. This leaching is not so rapid 
in clay lands, but where the entire ammonia content of fertilizer used on clay is derived from nitrate of soda the accumulations of sodium will be enough to pack the soil. Reasonable amounts have no deleterious effects, and such results never occur on open lands because sodium compounds leach away so rapidly.

Nitrate of Potash is organic. The nitrate has the same properties as described in nitrate of soda, and the potash the same as will be shown under sulphate of potash, but this material does not dissolve quite as readily as nitrate of soda. As plants use both elements, nitrate of potash is a neutral compound in its action. It is used in many manufactures and its maiket price is far in advance of its true worth to the grower.

Cyanamid is often called line nitrogen. It is inorganic. Its plant food is in the form of nitrogen and must be changed to ammonia and then to nitrates before it becomes available to the plant. The other part consists largely of lime and carbon and of some com. pounds of iron, silicon, etc. Some cyanamids have a nitrate mixed with them to furnish plant food while the slower cyanamid is coming into availability.

Calcium Nitrate, like cyanamid, is a combination of air nitrogen with lime, but in this instance the nitrogen is in the form of nitrate and therefore an immediate plant food. Calcium nitrate, often called lime nitrate, is so soluble it becomes liquid when exposed to moist air. This is, in a measure, prevented by adding lime to a hot solution of calcium nitrate, making "basic calcium 
nitrate," carrying only about 12 per cent. ammonia instead of the 15 to 17 per cent. as in the commercially pure calcium nitrate. In both cyanamid and calcium nitrate the acid radical is used by the plant and the lime left as a neutralizer.

Dried Blood is organic - a packing house by-product. It carries its ammonia in form of nitrogen, but the material is so finely divided and so congenial to bacteria it becomes available fully as soon as sulphate of ammonia. All organic sources are soil builders, but with the exception of Peruvian guano and tobacco stems, they are attended with more or less acidity,-animal products less than vegetable matter, and dried blood least of all animal products.

Tankage is organic,-a packing house by-product, carrying both ammonia and phosphoric acid. Its ammonia is in form of nitrogen and is a little more slowly available than sulphate of ammonia. This is a valuable material for use in mixed formulas with nitrate of soda and sulphate of ammonia. About half its phosphoric acid is available when applied, and the rest soon comes into availability through the decomposition of organic matter. There are, ordinarily, at least three grades of tankage on the market, some carrying more actual plant food than the others, but every particle of tankage is of value to the grower as a soil builder. See Dried Blood as to acid tendency.

Ground Fish Scrap is organic. It carries ammonia and phosphoric acid in same form as tankage. It should 
never be used in the orange grove. It is a fine fertilizer for vegetables but greatly induces cutworms.

Sheep Manure is organic, and carries most of its ammonia in the form of nitrogen. It has much the same effect on soil as stable manure with two exceptions: It has been sterilized, therefore carries no weed seeds or germs of fungous or bacterial diseases, and is repulsive to soil insects instead of attractive to them.

Ground Bone, Raw or Steamed, is organic and carries ammonia and phosphoric acid. The ammonia is in form of nitrogen. About one-third of the phosphoric acid is available at time of application, but the rest becomes available gradually as the organic matter decomposes. Bone tends to sweeten land.

Pulverized Tobacco Stems though from vegetable source, are so dry and of such nature as to produce no fermentation during decomposition. They carry ammonia and potash in vegetable compounds that are especially pleasing to plant life. The nicotine content makes this material distasteful to worms, but only in quite liberal applications will this be strong enough for practical results. Their high cost is the great drawback to extensive use.

Cotton Seed Meal is organic, carrying ammonia in the form of nitrogen. It is a fine fertilizer on cold wet lands, as its decomposition is attended by so much heat. For this same reason it burns crops on lighter, drier soil. It has a tendency toward producing coarse fibrous vegetation and a strong attraction for soil insects. Cotton seed 
meal is expensive compared with other fertilizer materials and really should be used for stock feed, as about ninety per cent. of its fertilizing value will be found in the manure,- that is, if the manure is properly saved.

Castor Meal is organic, carrying ammonia in form of nitrogen. It has practically the same availability and value as a soil builder as cotton seed meal but is not so burning and is repulsive to insects, therefore is to be preferred as a fertilizer material.

Dissolved Bone Black-Though this material was once bone, the organic matter has been entirely burned out and it is a strictly inorganic fertilizer. It is the same as superphosphate except it carries no iron and aluminum.

Superphosphate carries phosphoric acid in water soluble form, which is inmediately fixed by chemical reaction, though still perfectly available to plants. When the phosphoric acid is used by a plant the lime combined with it is left to sweeten the soil. This amounts to about six per cent, but about sixteen per cent. more lime is in the sulphate of lime intermingled with the phosphate. This sulphate of lime acts neither as base nor plant food, but brings latent plant food, especially potash, into availability. The lime in the sulphate also acts in preserving the two to one ratio between lime and magnesia. With the phosphate and sulphate of lime there is about one-and-a-half per cent. iron and aluminum which are neither beneficial nor detrimental. Superphosphate is the most economical source of phosphoric acid 
at the growers' command. It furnishes phosphoric acid in a certainly available form and has no deleterious effects. This statenient is backed by scientists. It really would be well for growers to recognize the value of their own state product rather than to be led by interested people to lay to this material ills that befall their groves. It has been seen the phosphate has a slight sweetening tendency, and the only way sulphate of lime has an acid tendency is by combining with soil compounds to form sulphate of potash. When the plant uses the potash the sulphuric radical is left to unite with another base. This is easily supplied by crushed limestone for less than a twenty-fifth of what the potash would cost. I have previously explained that were this base not supplied the sulphuric radical would take the base from weaker acids and the resulting acidity would not be free sulphuric acid. I have gone into detail about superphosphate because there is so much wrong information being circulated.

Thomas Phosphate Powder (Basic Slag) is inorganic, carrying phosphoric acid, about one-third of which is available though not water soluble. The rest of the phosphoric acid may become available if the soil is acid or very rich in humus. There is about thirty to thirty-five per cent. of calcium, most of which is combined with phosphoric acid and silica. This will act with magnesia, but less than five per cent. is basic lime until the phosphoric acid is used by the plant. The iron content, as shown above, is of no value. The magnesia would be 
of slight value were this element not fully supplied by the low grade sulphate of potash, and the manganese would be harmful were there enough to make any difference, but there is not, so the buyer can be assured that none of these elements are going to hurt or benefit him and reckon the phosphate powder worth just what its content of phosphoric acid and lime is worth to him. Being inorganic this material is not a soil builder. It has an alkaline tendency.

High Grade Sulphate of Potash is inorganic, carrying water soluble potash which is immediately fixed in the soil in form available to plants. When the potash is used by the plant the sulphuric radical is left to seek another base. Sulphate of potash is practically the only source of potash at the citrus growers' command, but few formulas derive their entire potash content from the high grade.

Low Grade Sulphate of Potash-Since several have written to ask, it may be well to state that "double sulphate of potash magnesia" is simply another name for our old firiend low grade sulphate of potash, which is the standard source of potash supply. This material carries about half as much sulphate of potash as the high grade, and has about thirty-four per cent. sulphate of magnesia, which was taken up under Fads.

Muriate of Potash and Kainit carry potash in water soluble form but have a high content of chlorine. Citrus trees are sensitive to the ill effects of chlorine. Vegetables generally are not. Chlorine is repulsive to soil in- 
sects. About one-third of kainit is common salt, hence its burning properties.

Canada Hardwood Ashes carry a small content of potash in most desirable form, and about $33 \frac{1}{3}$ per cent. basic lime. They are expensive as a.source of plant food and neutralizer, but owing to their physical form often have a peculiar and beneficial effect on the soil. At times nothing else will quite take the place of ashes.

Land Plaster or Gypsum-This is sulphate of lime, which is fully described under Superphosphate.

Acid in Fertilizers-Several letter's have come to me asking if it is true that "ordinary fertilizers contain from 100 to 150 pounds of free acid in a ton." For the benefit of those who have not written, I will say, no chemist would uphold such statement. Fertilizers are either neutral or practically neutral when applied, and have acid or alkaline tendencies according to the portion-base or radical-used by the plant. Often the alkaline tendency of one material balances the acid tendency of another in a formula, some formulas being quite alkaline in their general effects. It is true that practically our only source of potash and only slow-acting source of ammonia for citrus trees have acid tendencies, but since this can be easily and cheaply counter-balanced by limestone, we need feel no concern. We also may bear in mind that most of our soils were acid before they ever had a pound of fertilizer, while as to the fertilizer,- - did it contain free sulphuric acid, the bags, tools, and hands of the 
user would all be eaten as only glass and lead can with. stand its attacks.

What Makes Soil Acid? This could be answered in three words,-Lack of Lime,-for there is no form of acidity that would not be corrected by the presence of basic lime; but a list of acid-producing causes will not be out of place:

Decaying of roots left when clearing away virgin growth.

Lack of drainage.

Turning under of green vegetation.

Cultivating land when too wet, especially in hot weather.

Burning sun on bare, moist soil.

Natural leaching away of the small lime content com= mon to most Florida soils.

Leaching- "Ammonia" leaches away as soon as it becomes actual plant food unless used by plants, but the loss of phosphoric acid and potash is insignificant. Lime, sodium, and magnesia all leach away rapidly. 


\section{Chapter $\mathbf{X}$ \\ Plant Constituents}

Plants of all kinds, whether garden vegetables or fruit trees, are alike in their constituents and mole of growth. Though other elements are shown by chemical analyses, the essentials for plant growth have been found to be oxygen, hydrogen, nitrogen, carbon, phosphorus, sulphur, potassium, calcium, iron, and magnesium; or, as Brooks puts it: "Air to breathe and water to drink; four acids,carbonic, nitric, phosphoric, and sulphuric; and four bases,-potash, lime, iron, and magnesia."

\section{$\underline{\text { Air }}$}

Oxygen-The plant uses oxygen in two forms: Combined oxygen which enters the plant through the roots in connection with other elements which are used in the form of oxides and the free oxygen of the air. This latter is absorbed by all living plant surfaces, but more abundantly by leaves and tender growing parts. Free oxygen in the soil is essential to plant life (except swamp regetation): Germinating seeds require an abundance and when roots are deprived of air the plants soon suffocate and die. The absorption of oxygen is accompanied by a giving off of carbonic acid gas-a product of the breaking down of living matter worn out by the "energy of growing" and of parts going to decay, as in injured tissues or faded flowers. This process is called "respiration." 
Carbonic Acid Gas-Carbon is the element which is most abundant in the dry matter of vegetation, its amount being about equal to all others combined. Though carbon dioxid exists in great quantities in all fertile soils and has a far-reaching influence on fertility, the carbon used by plants is taken from the carbonic acid gas of the air. This is absorbed by the leaves and other green tissues and through the action of the green matter (chlorophyl) under the influence of sunlight is combined with the hydrogen and oxygen of water to make starch, sugar, acids, oils, gums, etc., and cellulose-the substance in cell walls. This process of the formation of plant food from carbon dioxid and water and the throwing off of the unused oxygen is called "photosynthesis." It is the reverse of respiration, and since the plant's activities are much greater in photosynthesis than in respiration, vegetation removes from the air far more carbon dioxid than it gives off, and gives off far more oxygen than it uses, thereby purifying the air for animal life, which, on the contrary, uses oxygen in great quantities and gives off carbonic acid gas.

\section{Water}

It has been seen that the elements of water play an important part in the formation of different regetable compounds, but the uncombined water in plants is equally important. The rigidity of tender vegetation is due to 
its water content. Cut a succulent branch, and how soon it becomes limp and wilted! Plants cannot carry on the process of growing without sufficient water content, as all cells must be properly extended, and, too, water must be the carrier of all substances within the plant.

How Plants Feed-There are no openings into the roots, nor from cell to cell; all plant food, whether in raw or digested state, being moved in solution by osmosis and diffusion. Osmosis means the passing of liquids or gases through a membrane in accordance to Nature's law that the density of the divided substances be equalized. Diffusion means the "spreading out" of each particular substance in solution to make the solution of that substance of equal strength throughout. Much has been said about the plant's "power to select," but the best authorities now agree in the opinion that roots have no power to reject anything dissolved in the soil water, regardless of how harmful it may be to the plant. However, plants grow according to definite law, each plant developing along the lines of its own particular family. Soil solutions are very dilute. Normally, the plant sap is denser than the soil water, though the sap seldom is heavier than one pound of solid matter to sixty gallons of water. While osmosis causes the more dilute solution to move to the denser one, diffusion tends to equalize throughout the solution the amount of each substance dissolved. The leaves (and in a lesser degree all live plant surfaces) are constantly giving off water-a process similar to evaporation, but called "transpiration." This tends to concen- 
trate the sap in these areas, therefore, the osmotic movement is (under normal conditions) ever upward. Plants vary, but it is estimated that they average to lift three hundred twenty-five pounds water for every pound of dry matter grown. Now, since the soil water must enter the plants with its varied solutions, it would seem that there were danger of harmful accumulation of matter not used by the plant, but here is where diffusion comes to the rescue. I will quote from King: "The loss of water by evaporation through the surface of the plant or the consumption of it as food, which tends to make the strength of the solution of those substances not used as food stronger, cannot result in a permanent increase of them in the plant, because, unless these substances are actually taken out of solution, they travel back toward the roots again and escape into the soil water so long as the solution inside is stronger than is that outside."

Perhaps further distinction should be made between plants using and needing different elements. Certain elements named under the heading "Plant Constituents" are needed because the plant cannot grow without them. Other elements-chlorine, silicon and sodium, the first two forming acids and the last being a base-are invariably found in plants grown under normal conditions; and still other elements such as manganese sometimes occur. These last elements are used but are not needed, as the plant could grow equally well without them. 


\section{The Plant}

In the foregoing the plant has appeared largely as a lay figure subject to mechanical law, but we must realize that this is true only to a certain extent. Life is something none of us can define, but it exists as truly in the vegetable as in the animal kingdom, and we will find not only family but individual characteristics. The grower is not all-powerful, but by studying these characteristics and developing the good, strengthening the weak, and repressing the bad, he can accomplish much toward bringing about ideal results.

Plants consist of three distinct parts : roots, stem, and leaves.

Stem-The stem is principally a connecting link between the roots and the leaves, and a frame work upon which the leares are displayed to air and sunlight; but more or less respiration and transpiration is going on and the surface should be kept clean of either vegetable or animal parasites that $\operatorname{cog}$ the pores (lenticels) interfering with proper functioning as well as actually abstracting support from the tissues of the host.

Roots-While the stem grows in all its parts, roots lengthen in only a small, area just behind the little hard cap which protects the point. It is only in this new area that osmosis occurs, for the tissues soon become clogged. The plant develops these feeding roots where moisture and food are to be found. When it is growing rapidly they are more numerous and the feeding surfaces are vastly 
increased by a growth of delicate root hairs. Generally speaking, a cutting or tearing of the roots works great damage to the plant, and every effort the plant has to make to push its root through compacted infertile soil in search of sustenance takes just so much from the net profit. For best results the soil must allow free root movement and provide the needed air and water. Roots take in free oxygen and give off carbonic acid gas. This carbonic acid gas is absorbed by the film of water around the adjoining soil grain. The water thus charged has great solvent powers and much natural plant food is in this way brought into availability. A deep, wide root system is of untold benefit to a plant as it gives so large an area from which to absorb water and with it the nourishment held in solution. To secure such a root system, put the soil in good mechanical condition, spread the applied plant food in a circle reaching from not too near the stem out a little beyond the outermost branches and while the plant is young cultivate deep enough to prevent the establishment of surface roots.

Leaves - The leaves are both the stomach and the lungs of a plant. Their digestive powers depend upon the green coloring matter. Too much emphasis camnot be placed upon the importance of leaves being in good condition. Some crops require less foliage than others, but no crop reaches the maximum when its leaves are covered with parasites or are pale from starvation or because of physiological disturbances.

Protoplasm-All parts of the plant are made up of 
cells. These cells are of different sizes and shapes according to the work they have to do. They consist of the cell wall, in which is the protoplasm, a semi-liquid jelly. like substance surrounded by a thin, strong elastic membrane. This protoplasm is the living substance of the plant. In it the chemical changes take place-the breaking down of different compounds; the formation of various vegetable substances,-starch, sugar, etc.; and the use of these substances to the plant's best advantage. The work within the plant is very intricate and is not thoroughly understood by anyone, but it will serve our purpose to consider that the soil water enters the roots, rises to the leaves where it is elaborated (digested), and returns by way of the inner bark to the different parts of the plant where it is needed.

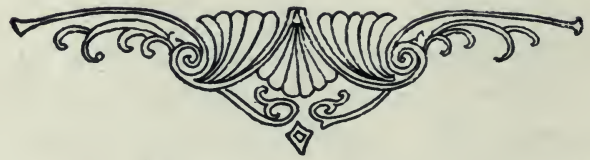




\section{Chapter XI \\ Fertility}

Perhaps the most important lesson for the prospective grower to learn is that fertile soil is not an inert mass but, instead, is teeming with living organisms too small to be seen with the unaided eye but of inestimable value. Then he must also learn that there are other organisms just as ready and powerful to work against him if soil conditions are allowed which are favorable to their development. These micro-organisms (called "micro" because they are seen only through microscopes) are innumerable forms of both vegetable and animal life,bacteria, fungi, etc.-the bacteria having by far the greatest influence on agricultural conditions.

\section{$\underline{\text { Bacteria }}$}

Lipman says: "In agriculture, the development of bacteriology has given us a new insight into the nature of soil fertility. We have learned to regard the soil as a culture medium with its almost endless number of species and varieties of bacteria, specialized to do important work in the transformation of soil nitrogen, carbon, hydrogen, and sulphur; in the transformation, also, of compounds containing lime, magnesia, phosphoric acid and potash. We have learned to reckon with these organisms in our methods of soil improvement, and have made some progress toward successful systems of soil inoculation." Bacteria are the simplest and smallest forms of vegeta- 
tion, being one-celled plants and so tiny 25,000 could be placed side by side in a line an inch long. However, the multiplication of bacteria under favorable conditions is beyond our conception, and what they lack in size is made up in numbers. Favorable conditions for the development of one form of bacteria may be most unfavorable for another; the most noticeable distinction being that some (aërobic) require an abundant supply of air, while others (anaërobic) flourish where the circulation of air is limited. Certain conditions are unfavorable to all bacteria: dry sandy soils lacking in humus contain very few; pure clay soils are equally barren; and also any soil that is filled with stagnant water or that is strongly acid. Many bacteria are killed by drying, while others only remain dormant. It has been found that in the decomposition of regetable matter there is very little bacterial action when the moisture drops below twenty-five per cent.

Bacteria, like root hairs, take food by absorption through the cell walls, therefore, only dissolved substances can be used. To aid in this solution the bacteria give off secretions called "enzymes." Enzymes are strictly chemical substances which break down organic compounds but do not enter into combination. Organic matter is complex and the various changes are not fully understood, but either the enzymes themselves or the compounds they induce, or perhaps both, are under some circumstances "highly useful," but under others they are "intensely poisonous" because conditions govern the 
kinds of bacteria present. When green vegetation is turned under or a soil is saturated with water, "putrefaction" and its poisonous products occur in place of the "decomposition" which attends dead vegetation in an aerated soil. However, there are some forms of organic matter, which, under the most favorable conditions, produce enough of these poisons to affect citrus trees seriously, for the citrus family is especially sensitive to the action of such compounds.

Ammonifying Bacteria-The change from organic nitrogen to ammonia "is accomplished by many kinds of bacteria, . . . some of them are aërobic, others anaërobic. . . The formation of ammonia from organic nitrogen compounds in soils depends upon a variety of conditions, such as the kind of protein, the kind of soil bacteria, and all the physical and chemical conditions that modify or influence their activity." It is during these processes that the above-mentioned enzymes and their products occur.

Nitrifying Bacteria-Though the change from organic nitrogen to ammonia is so varied and complex, "the conversion of ammonia into nitric acid takes place as the result of two distinct bacterial chemical operations, one kind of bacteria being responsible for the first operation and another for the second;" these two chemical operations being the change of ammonia into nitrous acid and of the nitrous acid into nitric acid, in each instance by an addition of oxygen. These acids are immediately neutralized when there is free base present. If such base is 
not at hand the nitrifying bacteria will soon be killed by their own product. Van Slyke says: "Each pound of nitric acid formed, calls for nearly a pound of calcium carbonate." "Nitrification cannot . . . take place in acid or sour soils. In order that there may be no accumulation of free nitric or other acids in soils, it is absolutely necessary that there shall be an abundance of some basic compound which can unite with the free acids and form salts that do not act injuriously on nitrifying organisms."

It has been seen that the change from ammonia to nitrous and nitric acids consists of combining oxygen with the nitrogen, hence it is evident that the nitrifying bacteria must have an abundance of air. "Water-saturated soils prevent nitrification by shutting off the air. Limited air supply is one of the important factors which explains the slow nitrification on heavy sod land and in clay soils." Temperature also affects bacterial activity. Crops start earlier on open, well-drained soil, especially if they have a southerly slope, because of the warmth inducing a more rapid formation of nitrates.

Denitrifying Bacteria-These are the enemies which flourish when by ill-advised cultivation we have discouraged the presence of the nitrifying bacteria. Nitrifying bacteria can take oxygen only from the air, but denitrifying bacteria can break down nitrogen compounds to secure the oxygen needed for their development. They change nitrates to nitrites, then nitrites to free nitrogen which escapes into the air and leaves the 
soil impoverished to the extent of these operations. Some people, knowing their soil is too wet to permit nitrification, apply nitrate of soda. Such application is of benefit, for the plants get part of the nitrates, but there is such a substantial loss through denitrification the grower will find it far more profitable to secure good drainage and keep his land in proper condition. Denitrification takes place also when a large amount of green vegetation is plowed under. By such course, fertility is lost instead of gained.

Fixation of Atmospheric Nitrogen-Another class of friendly organisms are the nitrogen-fixing bacteria. The ammonifying and nitrifying bacteria, though most valuable in changing nitrogen to available form, do not increase the soil content of nitrogen. These little friends, the nitrogen-fixing bacteria, take free nitrogen from the air and convert it into nitrogen compounds that can be used as plant food. There are two classes of nitrogenfixing bacteria: "(1) Those bacteria that live in the soil itself, independent of the presence of growing plants, and (2) bacteria that are dependent upon the presence of certain higher plants, living and working within the plant roots." Those of the first class which are known as "non-symbiotic" are seemingly of no great importance, adding little to the store of combined nitrogen.

Those in the second class are called "symbiotic." The word symbiotic means "living together," but it is customary to use this word only when the association is of mutual advantage. In this instance the bacteria give 
nitrogen compounds in exchange for sugar and other carbohydrates manufactured in the green leaves of their hosts. The bacteria enter tender roots and multiply rapidly. As the colony of bacteria grows the root cell expands, forming a "nodule." These nodules vary in shape according to the host, but careful examination will prevent anyone from confusing them with the distorted roots caused by "root knot."

Legumes-The hosts of nitrogen-fixing bacteria which are of profit to the grower are called "legumes," and those which particularly interest us here in Florida are the cowpea, velvet bean, and beggar weed. These all, but particularly the first two, grow on new land, and by their extensive root system do much toward bringing the soil into good tilth. The stems and leaves have a high nitrogen content, and enrich the soil by this as well as by the addition of humus matter if the crops are mowed and dried, and then disked into the land; or if they are kept for hay or used for grazing they make most valuable stock food. Under suitable conditions the bacteria will supply at least two-thirds of the nitrogen that is in the tops of the plant and over half of that in the nodules on the roots. In other words, they will take from the air enough nitrogen to make the crop and to leave the soil richer in this element than it was before the crop was planted.

Besides proper air and water content, secured by tilth and drainage, there are three main factors in making a crop of legumes profitable: 
(1) Base,-Though some legumes make a fair growth on soils more or less acid, they do not develop many nitrogen nodules and, therefore, are of proportionate value, often benefiting the land no more than any cover crop. Lime the land when it is not already slightly alkaline.

(2) Fertilizer,-Apply a formula giving enough and not too much available nitrogen to start the plant off well, and plenty of phosphoric acid and potash to provide for full development of crop. If a large quantity of available nitrogen is applied, the plant and bacteria use it in place of the nitrogen of the air, thus the bacterial benefits are lost; and if too little, the plant is slow in "starting off" for the bacteria have not sufficiently developed to be of much value until about blooming time.

(3) Bacteria,-Each host (except those closely related) has its special bacteria, therefore it is important that this particular organism be at hand. The bacteria associated with cowpeas and velvet. beans seem to be common throughout the State, but often beggar weed does not get a good start the first year. This lack can be overcome by "inoculation," or the introduction of the needed germs. The surest method for this is a scattering over the field of soil from land which has grown a good crop of the intended host.

This is not practical on a large scale because of expense of transportation, so our efforts must be confined to commercial cultures. So far, no method of preparing such cultures has been devised that insures their vitality; but a large percentage of the products of reliable manufac- 
turers is good and they are well worth trying. However, they will not increase a crop on land already well "seeded" with that particular bacteria, nor will they act as complete fertilizer. Such claims are exaggerations.

Drawbacks-Every good has its accompanying evil. Cowpeas induce root knot and should not be planted on land to be used for vegetables, peach trees or figs. Velvet beans grow so rapidly they are almost sure to over-run young trees despite the grower's best intentions. Beggar weed must be cut before it gets woody or its stems are extremely slow in decaying and in the meantime are a great annoyance. Beggar weed seems also to be a favorite breeding place of the pumpkin bug, which is most difficult to control, and at times does serious damage in bearing groves.

Popular Terms-Popularly speaking, the ammonifying, nitrifying and nitrogen-fixing bacteria are all called "nitrifying bacteria."

Other Bacteria-Lyon and Fippin say: "Certain bacteria decompose some of the mineral matter of the soil and render it more easily available to the plant." The disintegration of rocks, weathering of soil, changes in sulphur and iron compounds, and the action of various organic acids including carbon dioxide,-all are results of bacterial life. Van slyke mentions the products of bacteria, "carbon dioxide gas, nitrous, nitric, sulphuric, and various organic acids," and their effects upon calcium and other carbonates, phosphates, magnesium, potassium, etc., of the soil, as well as in substances applied in the 
form of fertilizer, and says: "These statements serve to show that extensive and far-reaching chemical changes are wrought by bacterial action. It is obvious that the more favorable the soil conditions are for the growth of bacteria, the more intense will be their activity and the greater the changes brought about."

\section{Fungi}

Fungi range in size from microscopic forms but little larger than bacteria to immense toadstools. They are of much higher organism, multiplying by the production of spores (seeds) in place of the simple division of bacteria. "Many soil fungi assist in decomposing organic matter, especially in the earlier stages of decomposition. They are particularly active in acid soils in which many bacteria cannot work."

\section{Animal Life}

Protozoa-Protozoa are one-celled organisms that in greenhouse conditions sometimes become so numerous as to destroy an appreciable number of nitrifying bacteria, but we are not likely to feel their influence in the field.

Root Knot or Nematodes - The adult nematode or eel worm is about three-hundredths of an inch in length. It punctures the roots and breeds therein, causing the formation of galls and inducing disease and decay. This trouble is popularly known as root knot. Rotation of crops and flooding the land are the only means of control known at the present time. 


\section{Chapter XII \\ Insects in General}

Practically, insects can be divided into four classeschewing insects that may be killed with stomach poison; sucking insects that may be killed with contact insecticide; insects like the weevil, the habits of which make fumigation necessary; and others like the plant bug and leaf hoppers, which even to check materially take all of man's wit.

The chewing insect can be distinguished from those which suck, by the mouth parts, the one having jaws, "mandibles," that work sideways, and the other a snout for piercing regetable tissue. The most of the insect damage to our crops is done by the young or larvae. Many are then popularly called "worms." Our cabbage is eaten by the young of a dainty white butterfly; wire worms are the offspring of beetles; while a fly much like the common house fly lays the eggs that hatch into root maggots. Broadly speaking, insects in the larval stage do us no good and do harm in proportion to their number.

If chewing insects feed in the open they can be killed with stomach poisons; for this either Paris green or arsenate of lead is generally used. Sucking insects, common examples of which are the aphids or plant lice of the garden, the different scales on various trees, and the 
citrus whitefly, puncture the outside tissue and feed upon the juices of the plant. Stomach poisons, therefore, are of no avail. For their control we must depend upon contact insecticides or fumigation. The principle of a contact insecticide is to kill the insect by entering its breathing pores, "spiracles," as they are called. 'The materials most commonly used for this purpose are tobacco, soap, or oil in some form. For the fumigation of ants, weevils, etc., bisulphide of carbon is generally used. It is very inflammable.

The subject of fertilizing is too great to be discussed in full here. A few plants seem to have no preference as to the source of their food, while many are most susceptible to the influence of different fertilizer materials. The plant's welfare must be given first consideration, but often we can combine fertilizing and insecticide effects to good advantage. Commercial fertilizer is less inducive to insect development than is stable manure, some forms being far more active in this way than others. Muriate of potash and kainit with their strong chlorine content tend especially to lessen insect life in all forms, and will do much to balance conditions made by the use of stable manure; therefore they are to be preferred to sulphate of potash for use in connection with it. However, to have such material act as a direct insecticide, as against cut-worms, etc., it is necessary to make a heavy application on bare ground. At least 1000 pounds of kainit should be used per acre. This can be put on after plowing and harrowed in, say, a month 
before planting. If rains come the potash will not be materially wasted, but the salt will be washed away, leaving the soil in condition to plant crops which would "burn" were kainit applied at planting time or after. Nearly all forms of insect life found in the soil succumb to the salty solution formed by rains on land dressed with kainit. Root knot is an exception, but its work can be slightly retarded by building up firm tissue in the root system through the use of commercial fertilizers high in potash.

There are three particular points in successfully combating either insect or disease enemies of our crops.

First, start in time. If the crop is ruined before spraying is commenced, insecticides and fungicides, however valuable, cannot effect its rehabilitation.

Second, do thorough work. Spraying half done is a waste of time and money.

Third, unless you have had experience try the spraying solution on a small area three days before spraying the crop, and watch its effects.

In further comment on point three I would say to the grower who declares he has "not the time to wait three days," that in such case he has let his enemies get ahead of him. Constant vigilance is essential. When the grower sees a flock of chocolate-brown butterflies hovering over his bean patch he can turn up the bean leaves, find the yellow eggs, and know then he must spray soon. Spraying material should be purchased with his fertilizer, seed, and other supplies, then there is no chance to lose 
a crop by miscarriage of freight or through other delays beyond his control. Insects do not come suddenly. There is ample warning if the grower will but look for it. It generally is not until the second or third brood that insects become so numerous as to work noticeable damage.

In regard to the necessity of trying the spray someone asks, "Can we not depend upon your directions?" He must remember I am not responsible for careless weights or measurements. If the results given by a dozen different operators measuring out ingredients be compared the inaccuracy of their work will be evident. In some mixtures this is not so important. In others, it means serious loss; then, too, the foliage of the same species of plant is far more tender under some conditions than others.

I might add a fourth "pointer." Do not spray in hot sunshine. Often the sun heats the drops of water so as to scald the plant and the spraying solution gets the blame.

\section{Friends or Enemies}

The natural enemies of our enemies do much toward keeping them in check. Each larva has its parasite, perhaps animal, perhaps vegetable, each parasite has other parasites until it seems strange the insect world is not entirely destroyed, but because of Nature's most delicate balance, the different combatants, when under natural conditions, keep in about the same proportion. Man disarranges this balance, therefore it is most essential that 
he knows which are his friends, which his enemies, in order that this interference may be turned to his advantage. Without going into deep study, we can safely consider insects resembling bees and wasps our friends; flies, butterflies, moths, ants and grasshoppers our enemies; while beetles are divided, though the greater number are against us.

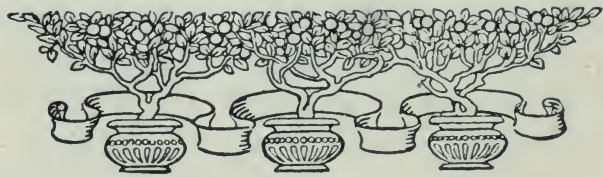




\section{Chapter XIII \\ Diseases in General}

One cannot fail to be impressed with the number of insects and disease troubles that may occur. He is almost inclined to feel despair in ever producing the crops when there is such an array of enemies awaiting him. But he should consider the matter in two ways: First, it is as impossible for all or even a small percentage of these troubles to attack a single crop as for one person to suffer from all the diseases common to the human family; second, that there is a preventive or remedy for nearly every trouble mentioned. Shutting one's eyes to evil does not overeome it. The best policy is to recognize all drawbacks and either avoid them or stamp them out.

Most plant diseases are caused by parasitic fungous or bacterial growth. We can imagine a fungus as a tiny plant, the spore or seed of which lodges upon a leaf, fruit or twig and sends out "roots" which enter the pores and make their way through the cells of the inner tissue, feeding upon the elaborated sap, taking ${ }^{\circ}$ the nourishment prepared for the plant's own use and clogging and disarranging the cells, causing disease and death to the attacked area. On the surface the fungus develops and produces quantities of other spores which are carried by dew, rains, winds, insects, etc., to other points where further infection can take place. Potato blight is a good example of this. The control of such diseases is based 
entirely upon so coating the surface of uninfected vegetation with Bordeaux mixture or other fungicides that when the spores fall upon it they are killed. This explains the need of thorough spraying. Unsprayed portions are as readily affected as though the rest of the plant were also unprotected. As long as new leaves are forming it is necessary to spray every ten days or two weeks until the disease is eradicated, even when the most favorable conditions prevail. Dry, sunny weather is against fungous growth, while cloudy, wet weather favors it. Hence, during cloudy days diseases spread more rapidly. If Bordeaux mixture has time to dry thoroughly before the rain falls it will be quite resistant to washing effects. This is true of other sprays to a great extent, but even if the fungicide used is washed off, it has killed myriads of spores which would have infected new areas. Spraying must not be delayed because of rainy weather. There are four distinctions for the grower to make when considering fungi, these being based upon the hosts necessary for their establishment. The class I have mentioned attack living vegetable tissue and are our "enemies," in that they work against us, but there are also "friendly" fungi, so called because they live only on animal tissue and by becoming established upon and killing our insect enemies, scale, whitefly, etc., they work to our advantage. Another kind of "noxious" fungi exists in our groves and gardens which can live upon dead and decaying matter, but when such matter is a weak or dead part of a live host the toxine, that is, the 
poisonous fluid, created by the action of the fungus will cause further death and decay until there is practically no difference in its effect and the effect of the fungus first mentioned except it must have a point for entrance. Citrus "withertip" and lettuce "drop" are common examples of the third class. In the fourth class are the "damping-off" fungi, of which there are several varieties. These live on decayed matter in the soil, but they are more virulent than those preceding, as they can attack perfectly healthy young seedlings of many plants. They enter the stalk at or near the surface of the ground, either starting decay there at once or clogging the water passages so the top of the plant wilts and topples over, after which decay rapidly sets in. Whole seed berls are thus attacked so suddenly that often the grower can do nothing to save his plants after the trouble first appears; therefore he should guard against it. Land known to be subject to damping-off should not be used for a seed-bed. Seed-beds should always be well drained and the soil kept aerated by constant stirring. Dry sulphur sprinkled on the surface and lightly scratched in is a good preventive. A spray of weak ammoniacal copper carbonate solution is also effective if given in time.

Bacteria differ from fungi in that they live wholly within their host, clogging the passages and thereby producing death and decay. Since they are entirely within the plant, spraying is ineffective. The entrance is often made through tender roots and the disease carried over the field by the feeding of insects from plant to plant. 
Bacteria are tiny one-celled plants and multiply by divisions instead of by a "fruiting" or a "vegetative" process. While the spores of a fungus represent the seeds of a plant or perhaps a mass of "slips" in a strong protecting case, the bacterium has but one spore, and that is itself, with such covering as to make it practically unaffected by uncongenial surromndings, but sensitive to a favorable condition upon the arrival of which it "springs to life" and multiplies with incredible rapidity.

The "resting" spores of both fungi and bacteria are often longlived. They remain longer in land allowed to "lie out" than in that worked and planted to crops not favorable for their development. But often when we think the land is lying out to eradicate some insect or disease trouble it is growing weeds to help develop the trouble we are wishing to overcome. There is no reason why land should be allowed to lie out. It can rest just as well by raising a suitable crop and with far more profit to its owner.

But besides the attacks of fungi and bacteria there are diseases which are physiological, troubles brought on by uncongenial surroundings, either in soil, moisture supply, temperature, wrong fertilization or ill-advised cultivation or several of these factors combined. These diseases are the least understood and there is perhaps no more promising field for the scientist than in their study. Plants have an individuality and those of the same kind vary as to their sensitiveness to surroundings. The well-developed seed from a vigorous plant produces 
an individual more hardy in every way than the seed which can barely germinate. Good seed will bring results in a field as markedly as will good blood in a herd of cattle. The hardy young plant will have a much better chance for its life than its weaker brother, for being mable to change their environment they must do the best they can with the conditions provided by the weather clerk and the grower. Generally speaking, though, the grower can to an extent overcome weather disadvantages. But suppose the grower fails to do his part; suppose the ground is water soaked and sour and the moisture constantly passing into the plant or tree is laden with poisonous substances. Is it strange that a "digestive" disturbance takes place? Or, suppose the materials containing the plant food create such conditions or the ground is so hard the roots are restricted in their development, and therefore fail to furnish the right amount of nourishment; or, suppose there is comparatively no available nourishment at hand, or that the roots have been bruised and torn by deep cultivation and through the drying out following that cultivation are left with no moisture within their reach. Will not some disarrangement or "breaking down" be likely to occur? Dieback in the citrus grove and white-bud of corn and strawberries are such instances. When the plant becomes weakened physically its enemies seem to hasten to take possession and only by strict attention can normal conditions be established. Sanitation is as essential in the field as in the home. 


\section{Chapter XIV \\ Spraying}

Since too much emphasis cannot be laid upon this point, I will repeat: Careless spraying is a waste of time and money.

How to Spray-Cover the foliage with a thin film and stop just at the point where drops would be formed to run off. An excess wastes the spray, leaves the surface unprotected since the solution runs off instead of forming a film, and perhaps causes injury to the plant tissues at the points where drops hang suspended instead of falling, for when thus evaporated there is often enough of the concentrated solution to "burn" the vegetation.

Where to Spray-Study the insect or disease which is to be controlled and direct the spray accordingly. If the attacked area is the under surface of the leaves great care must be taken to have the work effective.

When to Spray-Never spray liquid in hot sunshine, as the leaves are often injured by the moisture being so heated as to scald them. This is also likely to happen if a light shower comes just after the spraying and the sun comes out hot for several hours afterward. While one cannot foresee the weather with certainty, he can generally judge it quite accurately for a few hours in advance. The ideal condition for spraying is a slightly cloudy day with a light breeze which will rapidly dry the foliage, 
for when once dry the spraying solution is not so readily washed off. Arsenate of lead, Bordeaux mixture and Yothers' Formula No. 3, an insecticide, a fungicide and a contact insecticide, respectively, are especially able to withstand weather conditions when once dried on the foliage.

Dust spray should be applied to dew-wet foliage when there is little or no air stirring. A slight misty rain after application is of benefit. During damp, rainy weather fungous growth develops much more rapidly, and fields should be sprayed oftener than in dry seasons.

What Form of Spray-Extended experiments have proved the wet spray to be the more effective. Where there is no local reason against it, I advise wet spray in practically all instances except for rust mite on citrus trees, mildew on beans, the cotton caterpillar and the corn-bud worm. The first because the dry sulphur is effective against the rust mite and not so active against the friendly fungi; the second, because the dry spray destroys mildew and it can be applied in the morning, when other work in the bean fields cannot be done, thus saving valuable time; the third, because it is so economical in labor since the slight dust jarred through the bags by the mule's movement is sufficient; and, fourth, because a tiny pinch of powder to each bud will do the work and a spray pump would be wasteful of both labor and mate. rial. In many gardens where team work is not used the dry sprays are more economical because of the saving of labor in carrying so much water. Such factors must be taken into consideration. 
How Much Spray-The answer to this question depends upon the spraying machine and the operator, also upon the size of the plants or trees. Fifty gallons per acre is considered an arerage amount of wet spray to be used where the crop is set in rows, like Irish potatoes; or one hundred gallons where the vines cover the ground, like watermelons. In the Maine Experiment Station they used from six to ten pounds per acre of dry spray with far better results from the latter, though from the plot receiving the ten-pound application the yield of potatoes was only about three-fourths that of the plot receiving the fifty-gallon wet spray. It is estimated by one grower that a citrus tree seven feet high by seven feet wide will need two gallons of spray, one $10 \times 12$, four gallons, and one $14 \times 18$, ten gallons, while another valued friend allows 750 gallons of spray per acre of large bearing trees.

As to dust spray-A prominent grower says that he used in two applications 1500 pounds of sulphur and lime dust on twenty acres of young grapefruit trees, and that out of 2000 boxes of fruit did not have over one box of russets. He used a dust blower run by an engine, and estimated the labor cost him about $\$ 10$. He says the extra value of his bright fruit (40 cents per box) more than paid for the spraying outfit, spray and cost of application. 


\section{Ideal Fertilizers}

\section{Best}

'ío gain a place on our regular list a formula must not only produce results, but results with a profit. The user of fertilizer considers the effect on his pocketbook the REAL result.

IDEAL, FERTILIZER produces the right effect, for it works with Nature. The preference of each class of vegetation for its source of plant food is carefully studied, as well as the proper proportions to give perfect balance -no lack, no waste.

With proper application of proper food, vegetation outgrows diseases and insects to a great extent, and being strong and vigorous, produces fruit that is pleasing to the eye and palate and brings financial returns that are gratifying to the grower.

Do not lose the maximum profit due you by poorly balanced plant food from improper sources. IDEAL stands for PROFIT.

\section{Cheapest}

With our long experience on the market with fertilizer materials in all parts of the world and ample capital to buy in great quantities at the most favorable times, and to obtain all concessions given for strictly cash sales, we buy our materials at the lowest possible prices.

Two of the leading railroads have laid their tracks to our factory and any ship that can cross the St. Johns bar can unload at our dock, so whether we buy at home or abroad, we secure the lowest freight rates, and delivery is made at our door. 
Our factory is equipped throughout with labor-saving devices, therefore our fertilizer is handled at minimum cost.

Our trade is so immense that the office expenses are much less per ton than is possible in a smaller business. Our every condition is favorable for economy and we give you the benefit. While we make the BEST, we can and DO sell the CHEAPES'T.

\section{Our Factory}

Is located on Idealia Point, in the eastern suburb of the city, on deep water. All vessels that can cross the bar can tie up at our dock, and we have rail connections to all parts of the Southern States. It is the largest and most modern factory in the South. Our main building is $400 \times 230$ feet and is supplied with the latest and best machinery for grinding and mixing. We have our own electric power plant. We are prepared to supply your wants quickly in any quantity that you may desire.

Remember that in buying Ideal Brands they are fully guaranteed and you know exactly what materials are used in their manufacture.

\section{Insecticide Department}

We carry all standard insecticide and fungicide materials, also the most effective and durable implements for application. Write for anything you want.

INFORMATION: We are prepared to give practical directions for combating insect and disease troubles. Tell us all about it, and if science has discovered or practice developed a method of control, the information is at your command. 



THIS BOOK IS DUE ON THE LAST DATE STAMPED BELOW

\section{AN INITIAL FINE OF 25 CENTS}

WILL BE ASSESSED FOR FAILURE TO RETURN THIS BOOK ON THE DATE DUE. THE PENALTY WILL INCREASE TO 50 CENTS ON THE FOURTH DAY AND TO \$1.00 ON THE SEVENTH DAY OVERDUE.

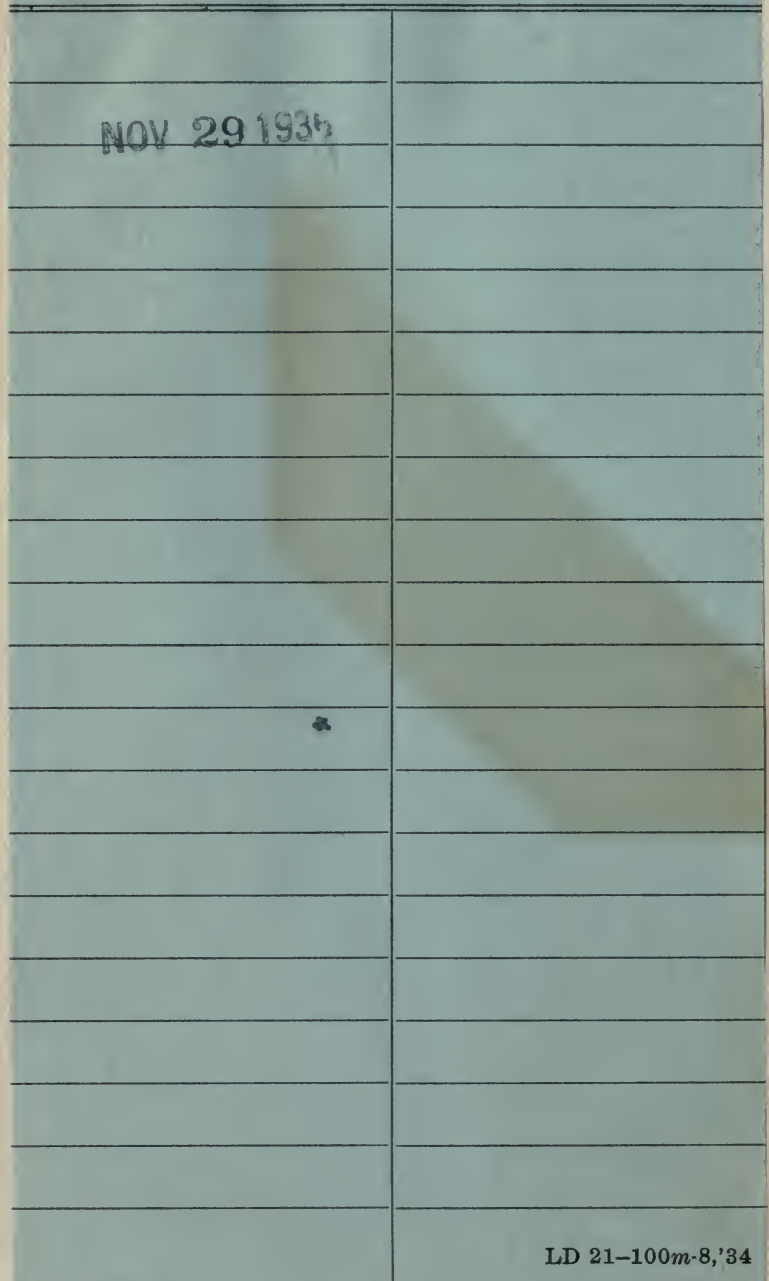




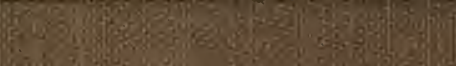

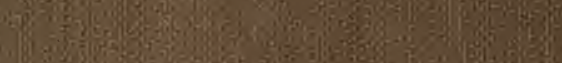

530 30 .

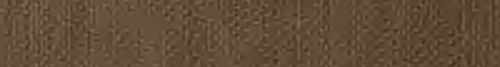

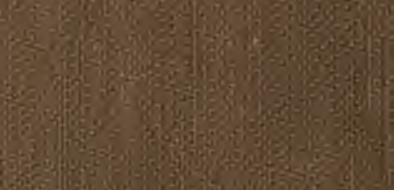

240 .

sise

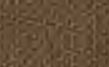

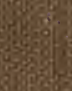

109

6.

acos

iser of

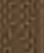

2.

28

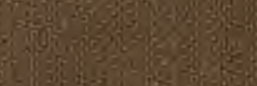

2.

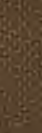

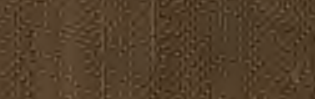

(2)

ofing: 